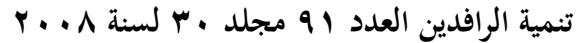 \\ كلية الإدارة والاقتصاد -جامعة الموصل \\ ص ص ص \\ دور المصارف في مكافحة ظاهرة غسيل الأموال لحماية الاقتصاد الوطني \\ دراسة تحليلية على المصارف العاملة في قطاع غزة الهان
}

\author{
الدكتور علاء الدين عادل الرفاتي \\ أستاذ الاقتصاد الممساعد \\ عميد كلية التجارة \\ الجامعة الإسلامية في غزة \\ فلسطين
}

\begin{abstract}
المستخلص

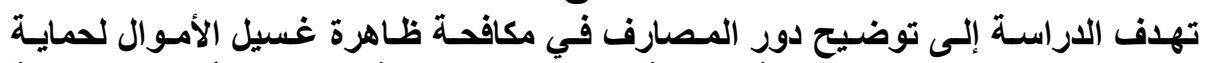

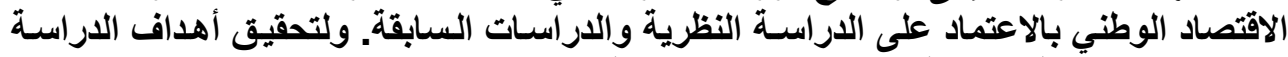

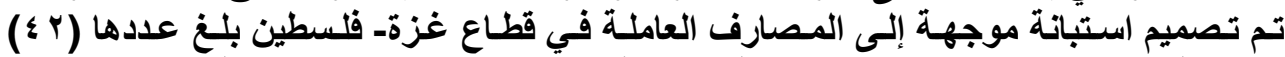

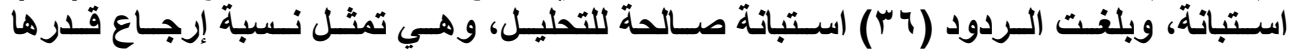

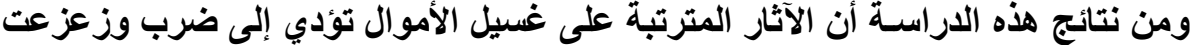
. (\%^०.र1)

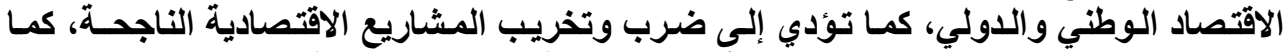

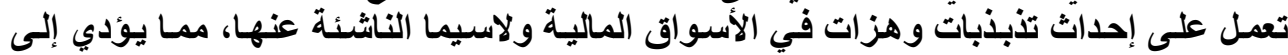

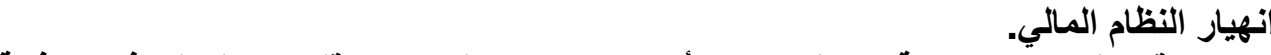
وقدم الباحث مجموعة من التوصيات أهمها: ضرورة التعاون الإقليمي والدولي في مكافحة

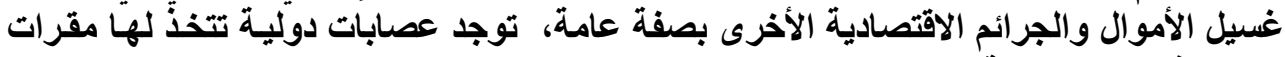

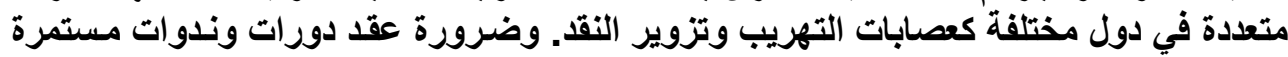

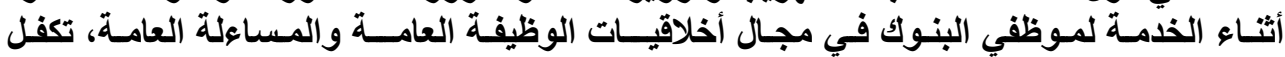
محتوياتها توعيتهم بقيامهم بواجباتهم نحو مكافحة غسيل الأموال القذرة.
\end{abstract}




\title{
The Role of Banks in Fighting the Phenomenon of Money Laundering For Protecting the National Economy: Applied Study on the Banks At Gaza- Province - Palestine
}

\author{
AlaaAldin A. Al - Rifaty (PhD) \\ Dean and Assistant Professor of Economics \\ College of Commerce \\ Islamic University in Gaza - Palastine
}

\begin{abstract}
The current study aims at identifying the role of banks in fighting the phenomenon of money laundering to protect the national economy. The study depended upon the theoretical and previous studies to achieve the objectives of the study. A questionnaire has been designed, addressed to the working banks in Gaza Province - Palestine. The questionnaires were (42), the respondents were (36) acceptable for analysis which represented (85.71\%). The results of the study showed the effects arising from money laundering are to upset the national and international economy. It also leads to the destruction of the successful economic projects. The vibration of the financial markets especially the growing up projects may lead to the failure of the financial system. The researcher introduced many recommendations. The most important among them is:

It is necessary to regional and international cooperation to fight money laundering and other economic crimes. This is because there are international bands having locations in different countries, such as currency fraud bands. The necessity of opening workshops during the service of bank's employees in ethics of public employment and public investigation the may enable them to support the fighting of money laundering.
\end{abstract}

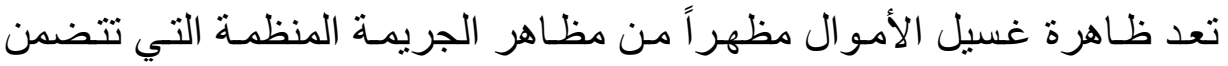

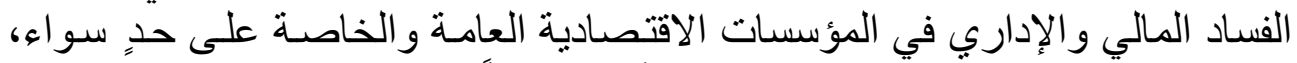

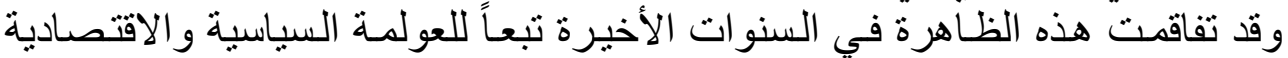

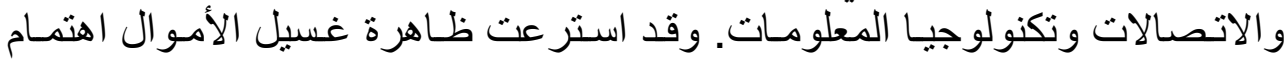

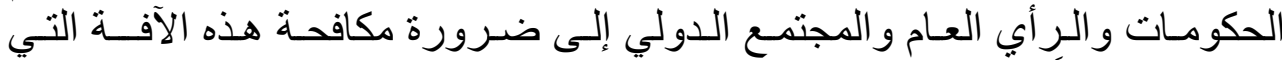

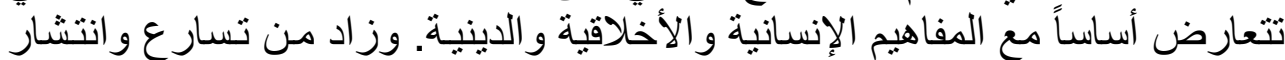

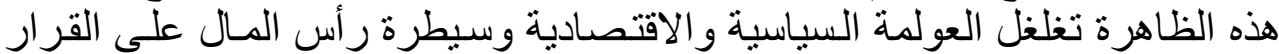

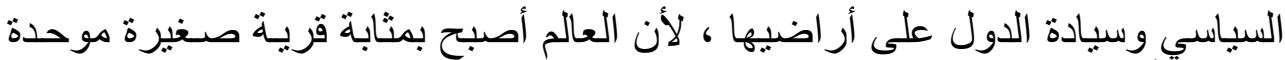

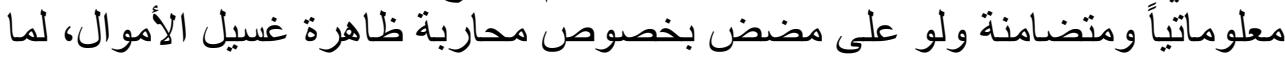

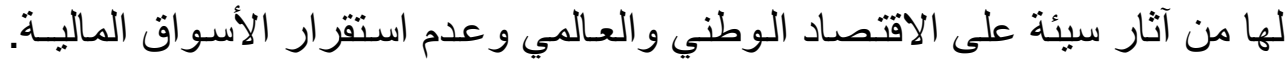

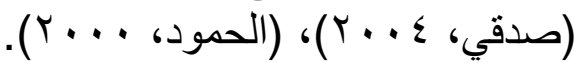
وتفشت هذه الظاهرة مع زيادة تقدم وسائل تقنيات المعلومات بفضل ما توفره من

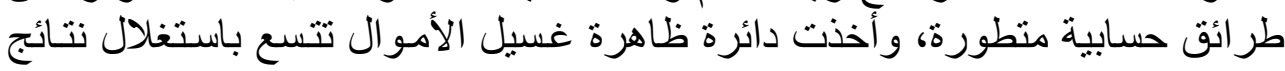

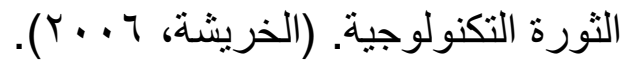




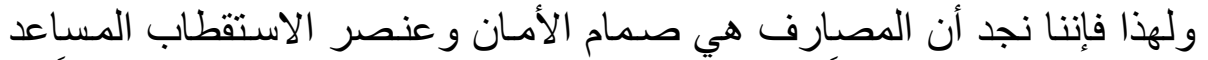

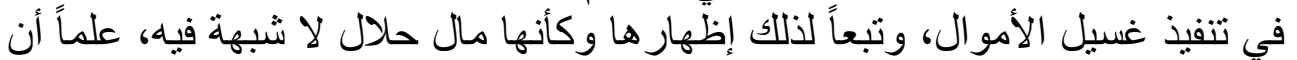

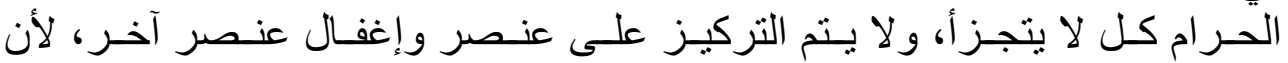

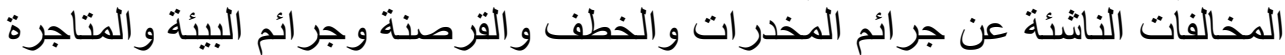

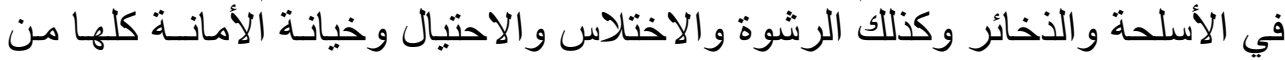

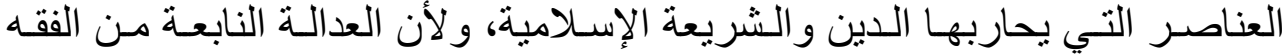

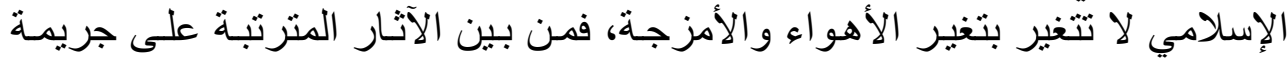

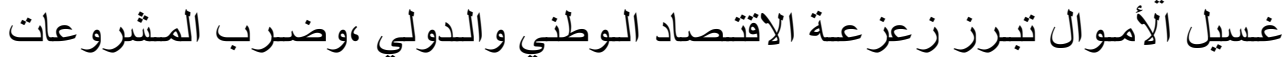

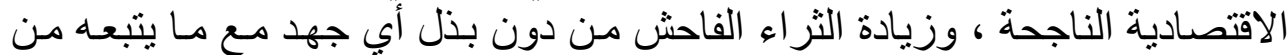

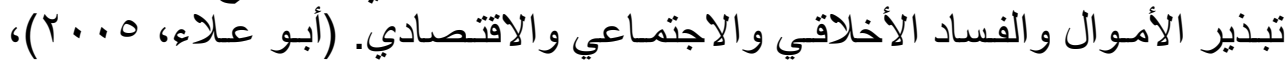
.(Michael Levi, 2000)

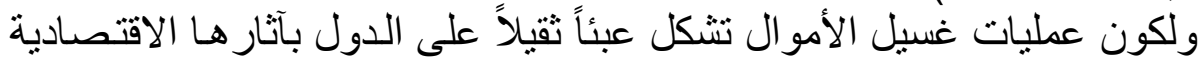

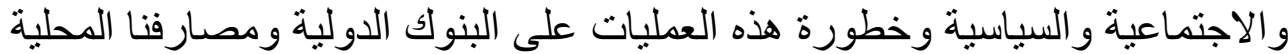

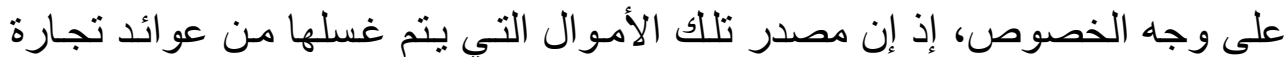

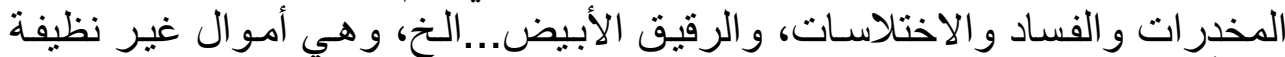

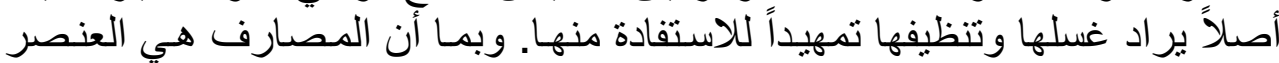

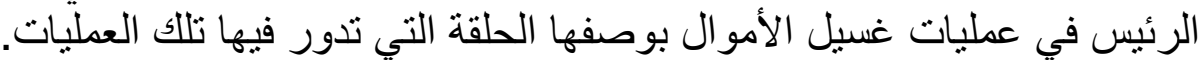

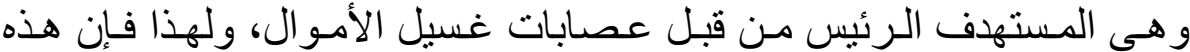

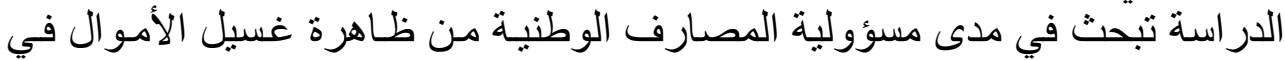

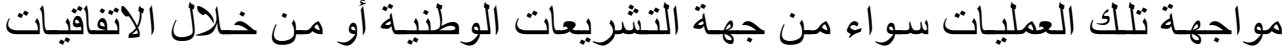

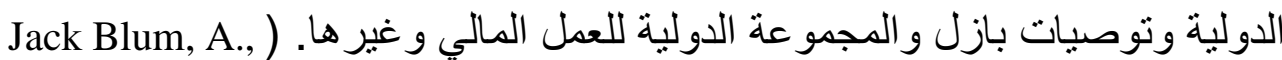

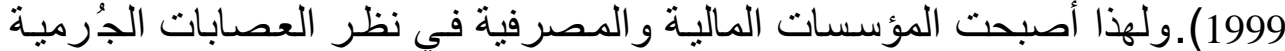

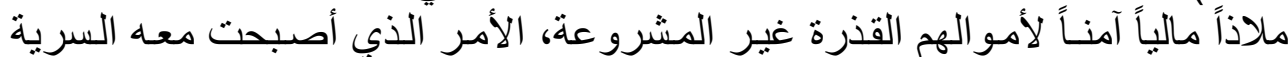

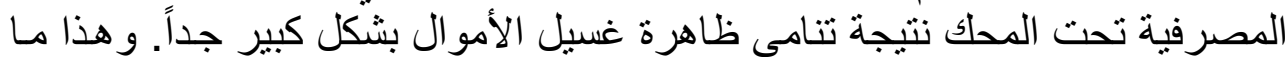

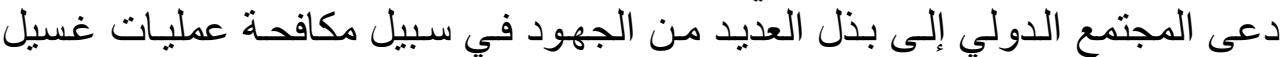

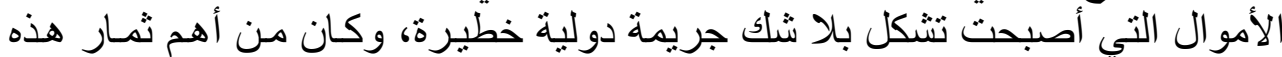

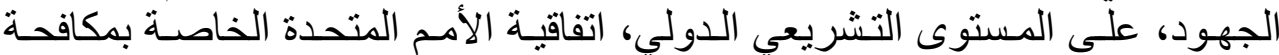

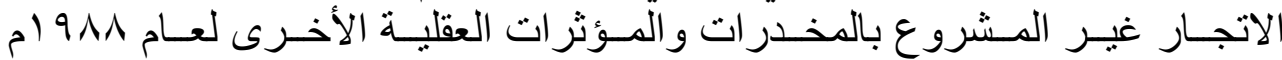

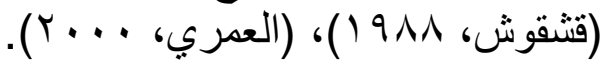

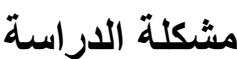

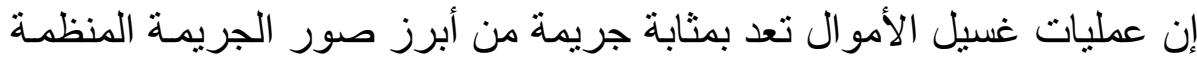

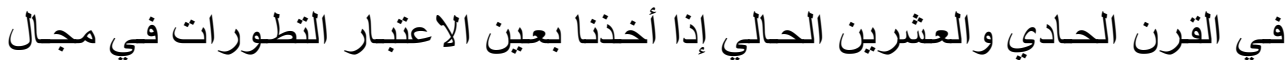

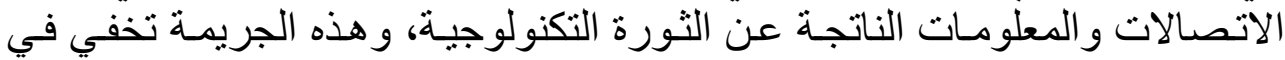

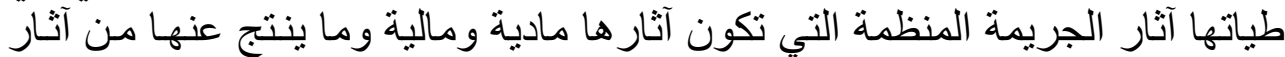

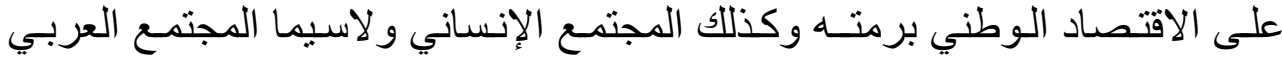

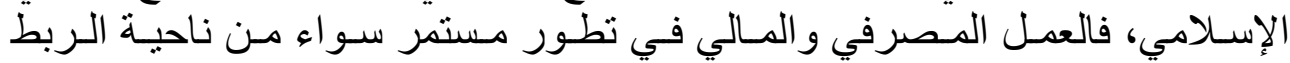




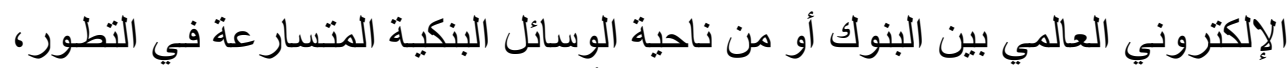

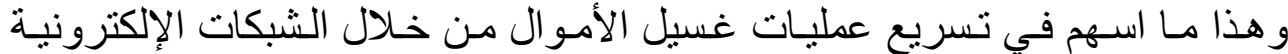

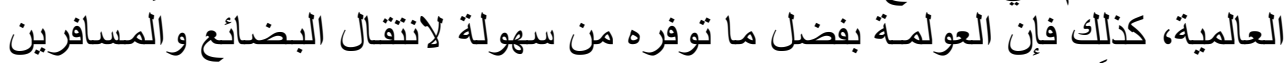

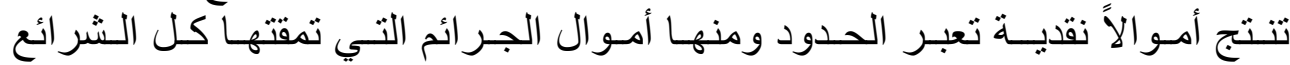
السماويـة.

و السؤال الرئيس للمشكلة مـا هو دور المصارف في في مكافحسة ظـاهرة غسيل الأمو ال لحماية الاقتصاد الوطني؟ ومن هذا السؤ ال الرئيس للمشكلة تتفر عُ الأسئلة

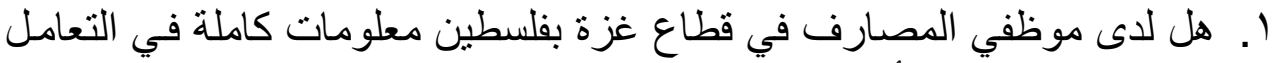

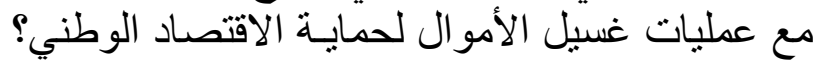

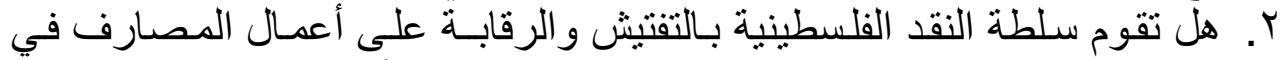

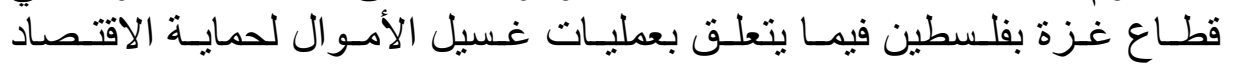

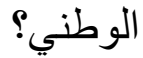

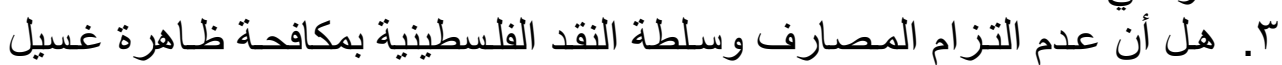
الأمو ال يؤدي إلى انهيار المؤسسات المالية الناجحة ويؤثر سلباً على الاقتصاد الطياد

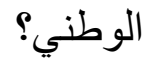

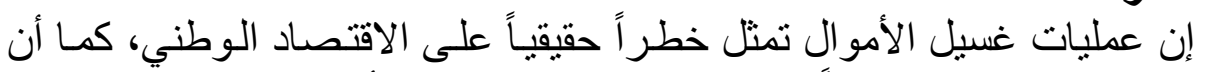
أهمية الاراسة

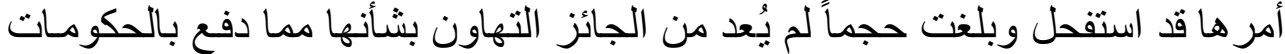

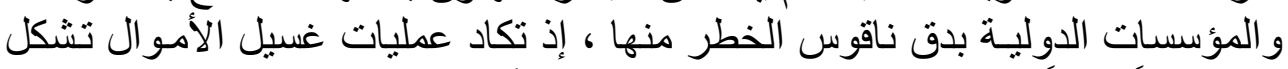

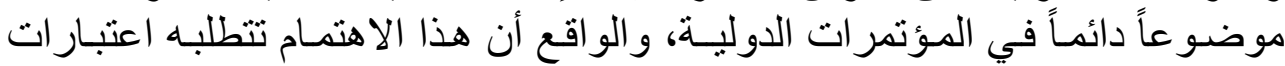

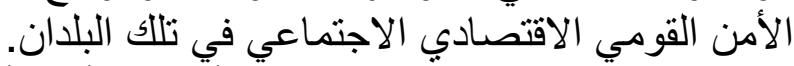

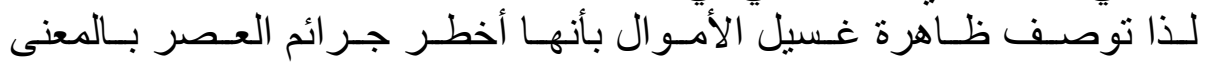

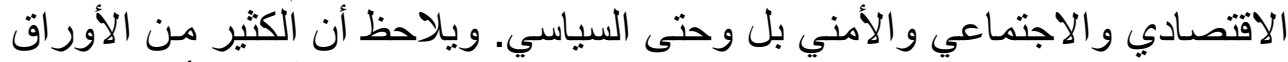

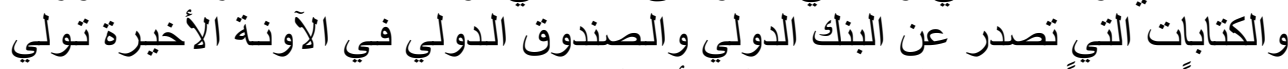

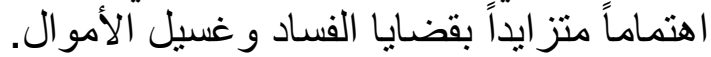

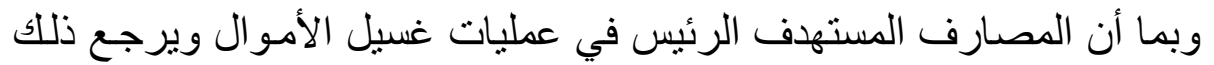

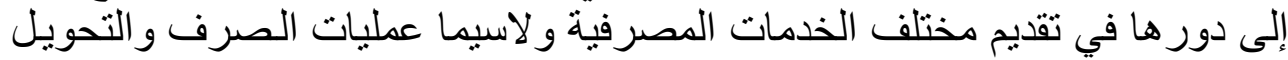

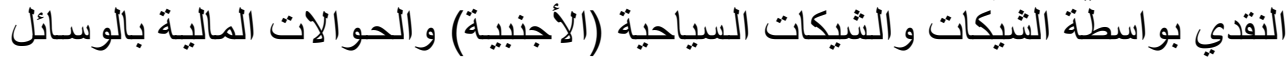

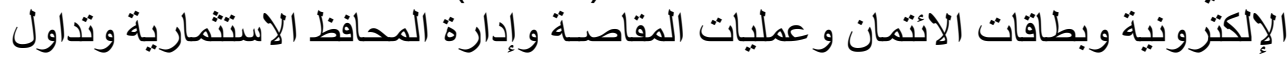

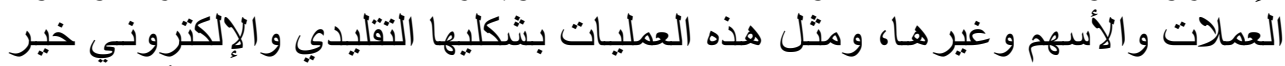

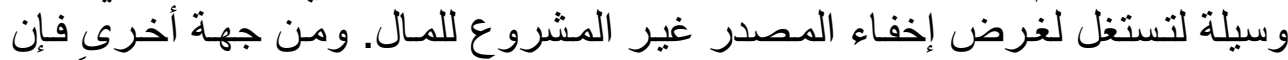

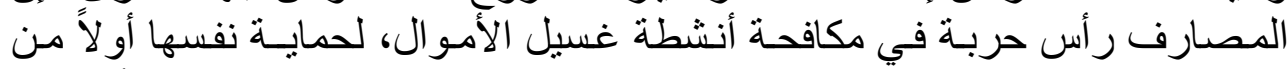

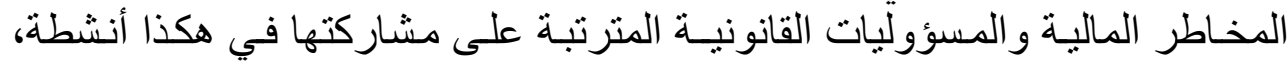
وللمشاركة الفاعلة في الجهد الدولي لمكافحة جر ائم غسيل الأموال. 
دكتور الرفاتي [1 [1]

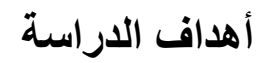
تهدف هذه الدراسـة إلى تحقيق ما يأتي:

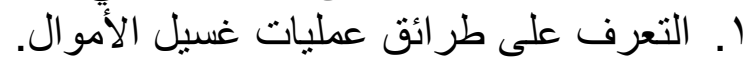

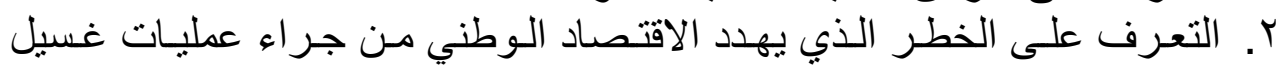

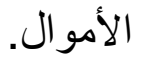
ب. ب. بيان الوسائل المستخدمة في عمليات غسيل الأموال. ـ. التعرف على الاقتصاد الخفي و أسبابه.

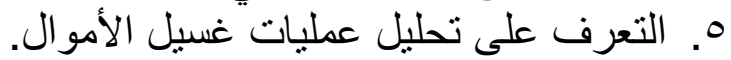

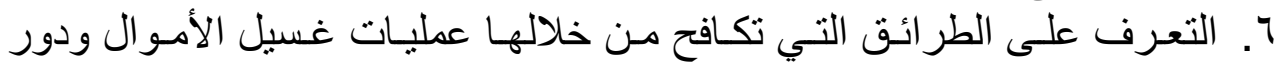
المصارف فيها. V. بيان الجهود المبذولة من قبل المصارف وسلطة النقد الفلسطينية بقطاع غزة

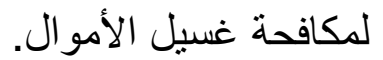

\section{فرضيات الدراسة}

لقد اعتمد الباحث في إجابته على مشكلة الدراسـة وأهدافها على الفرضيات

الفرضيـة الأولى النى

"لا توجد علاقة ذات دلالة إحصائية بين توافر المعلومات الكافيـة لاى موظفي

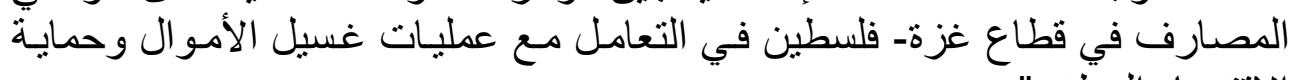

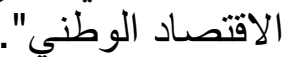

الفرضية الثانيـة

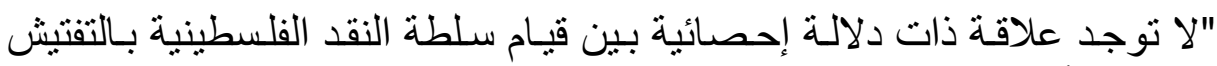

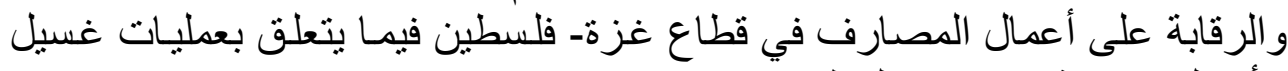
الأمو ال وحماية الاقتصاد الوطني".

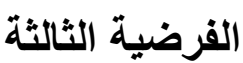

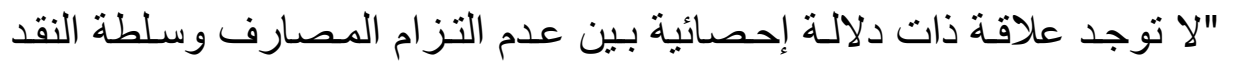

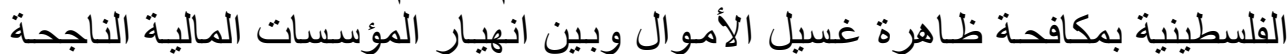
و التأثير السلبي على الاقتصاد الوطني".

هناك فيض من الدراسات تناولت ظاهرة باهن غسيل الأموال منها:

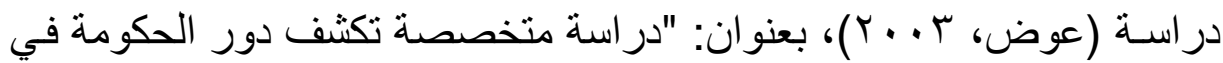

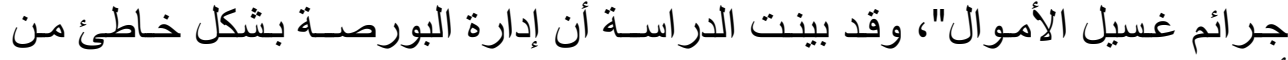

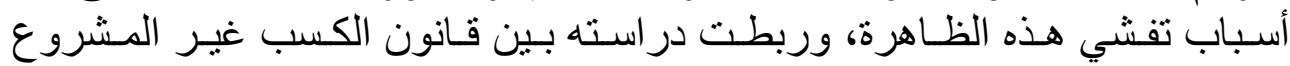


و عمليات غسيل الأموال في كثير من هذه العمليات يشارك فيها بعض العات الموظفين

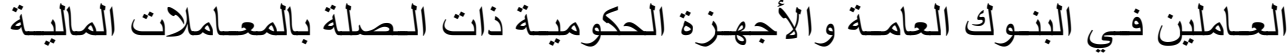

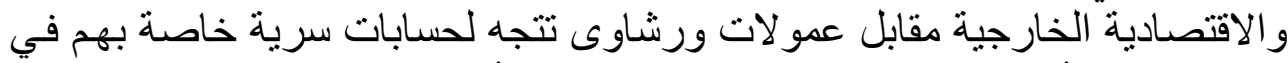

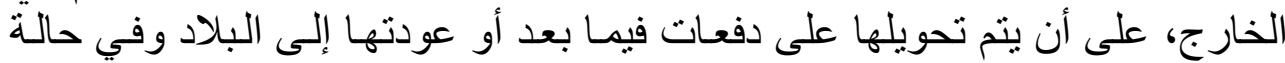

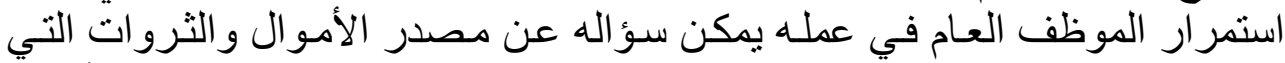

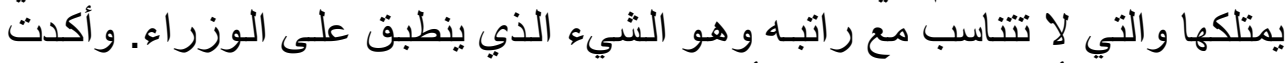

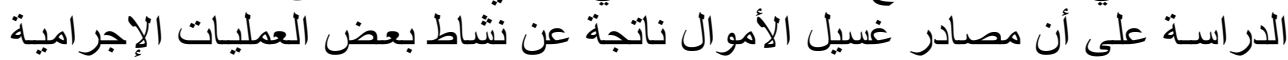

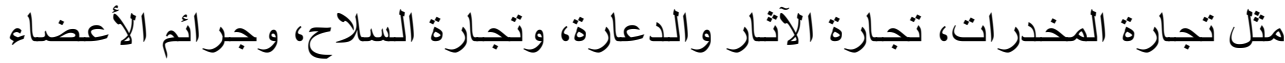

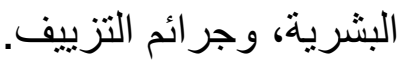

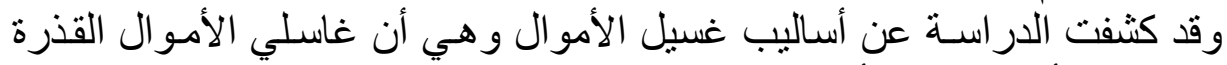

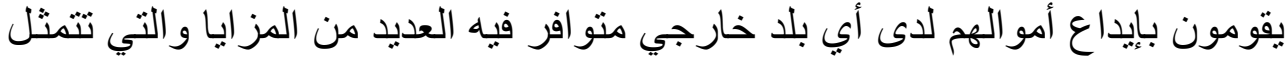

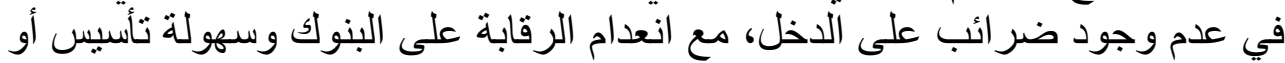

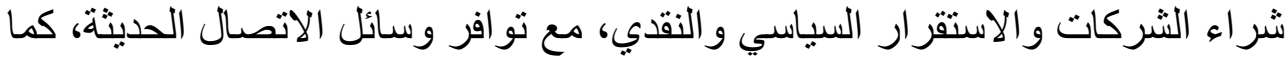

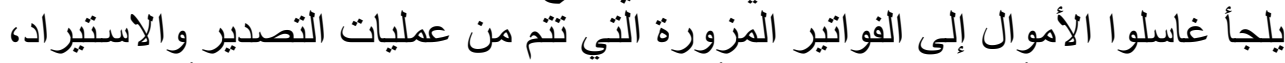

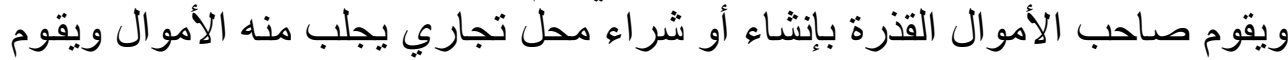

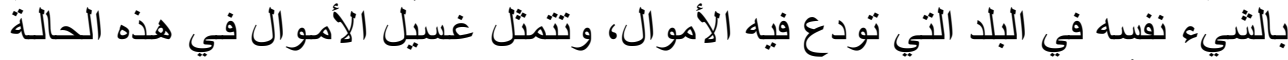

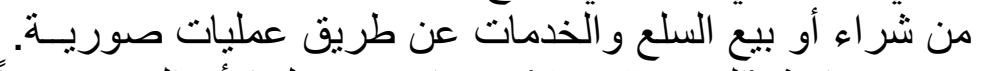

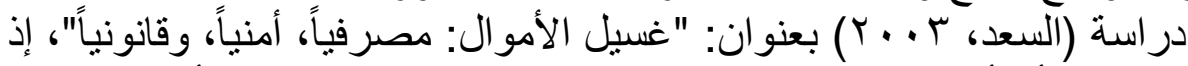

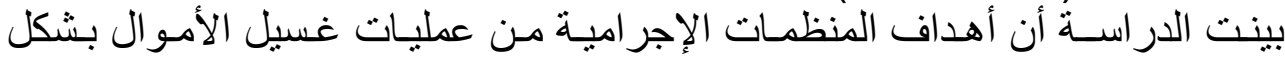

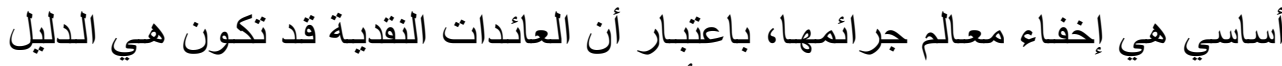

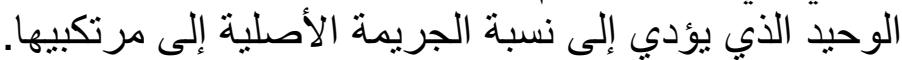

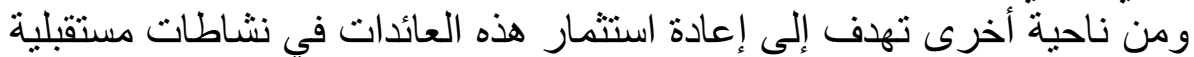

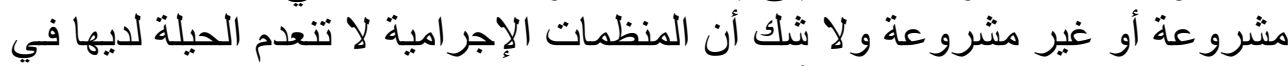

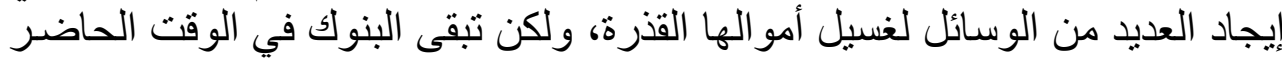

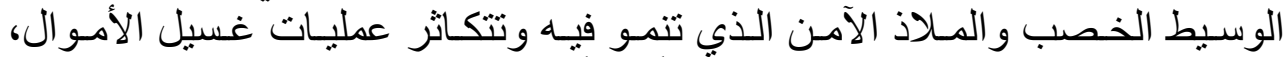

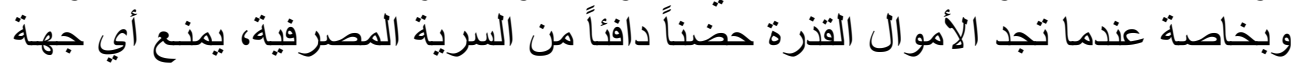

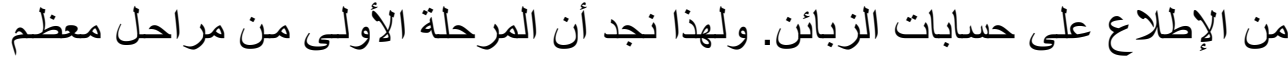

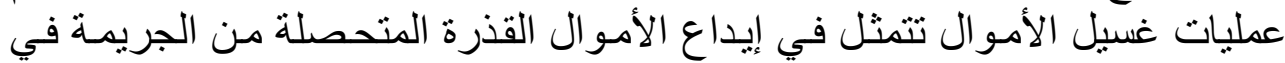

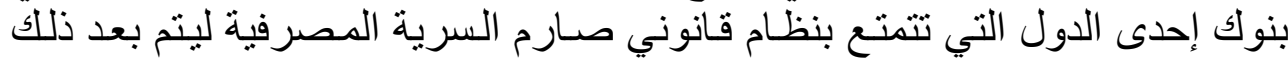

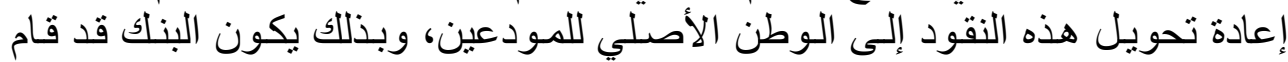

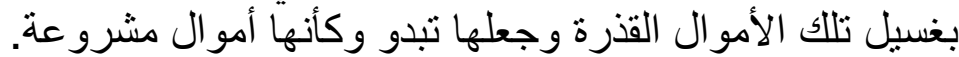

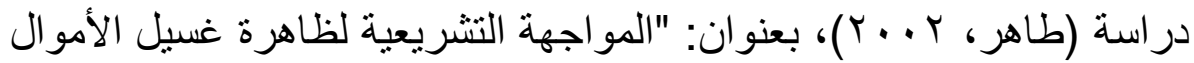

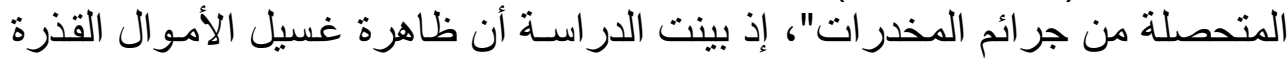

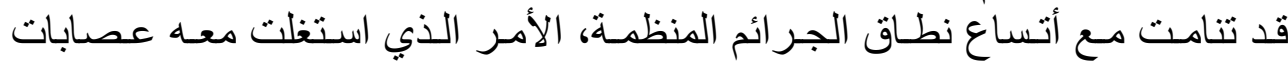

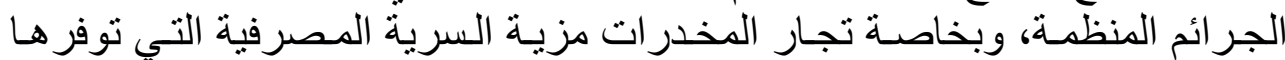

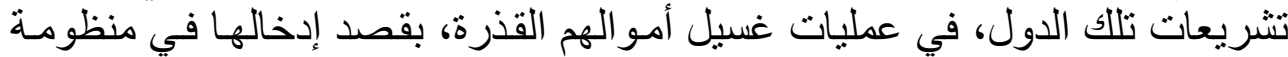

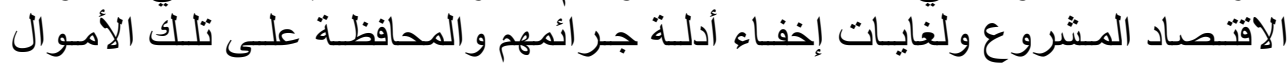


لتوظيفها مـرة أخرى في صفقات أخرى مشرو عة أو غير مشرو عة. كمـا بينت

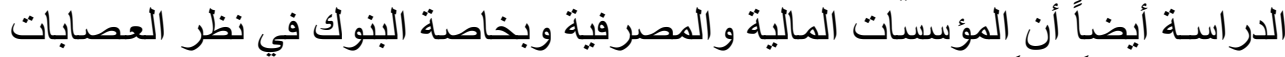

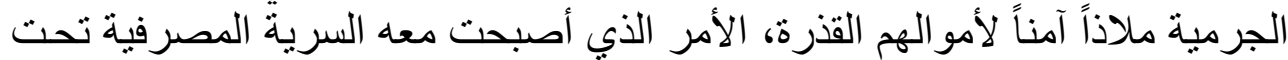

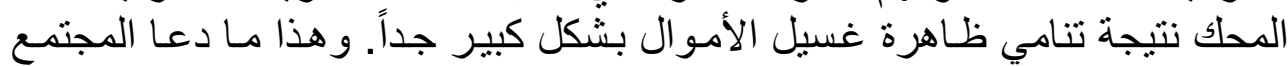

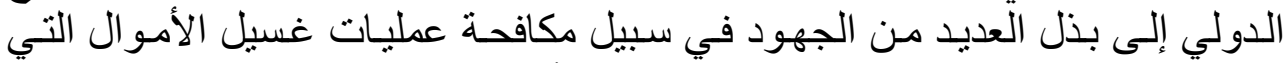

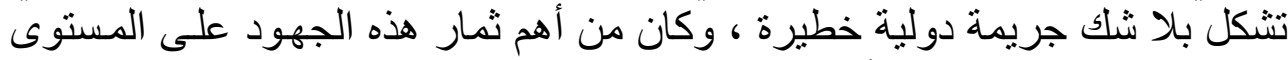

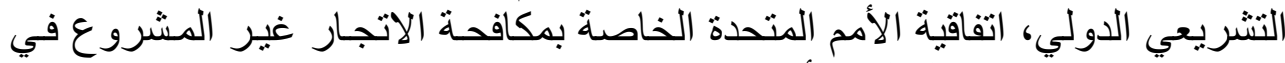

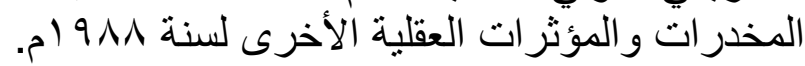

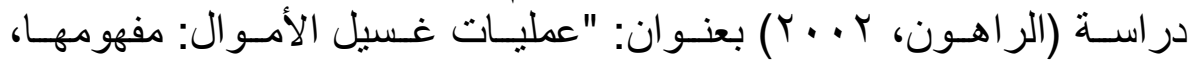

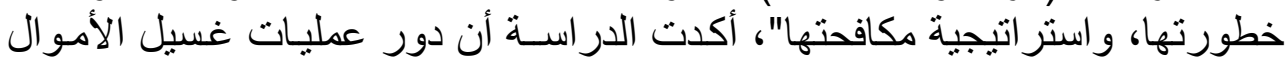

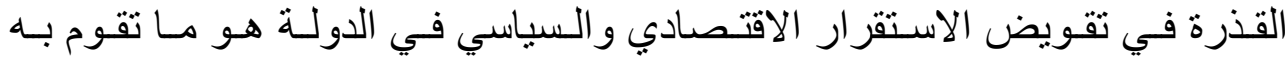

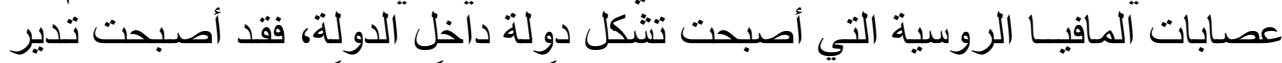

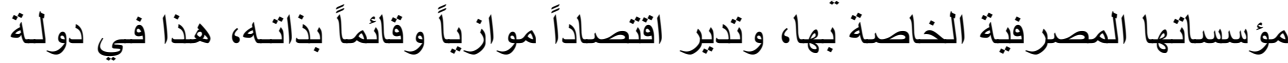

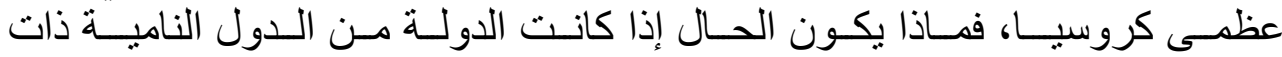
الاقتصناديات الهئـة.

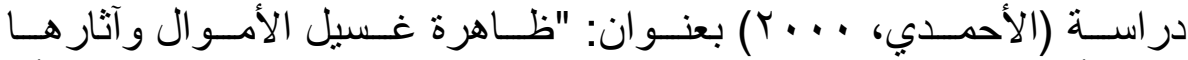

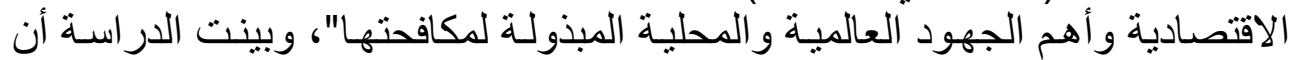

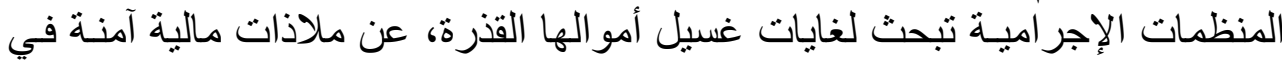

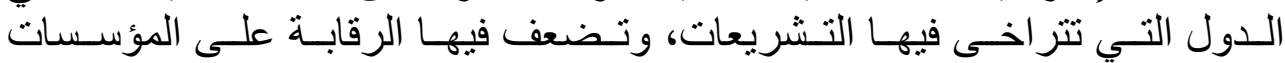

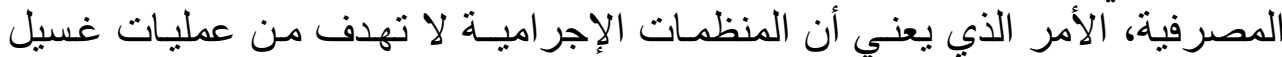

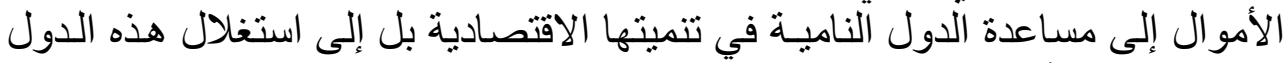

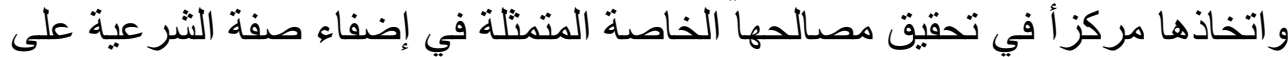

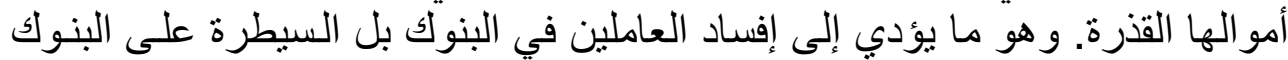

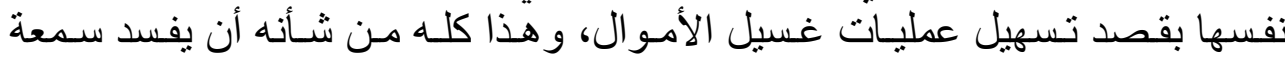

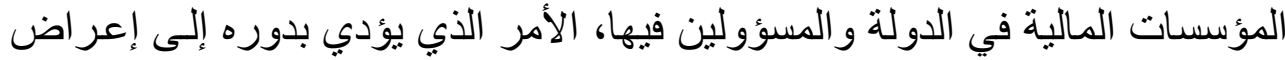

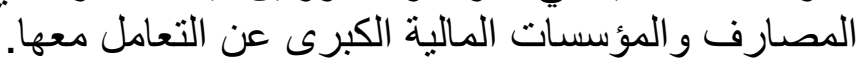

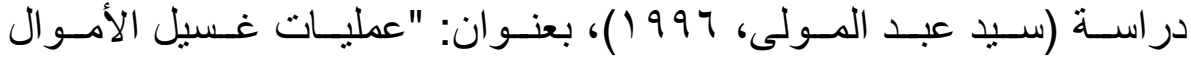

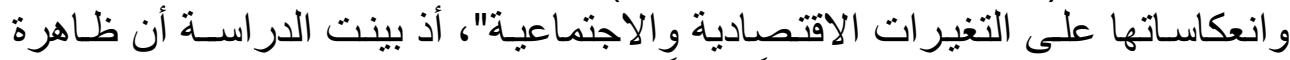

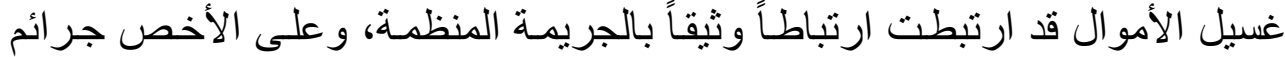

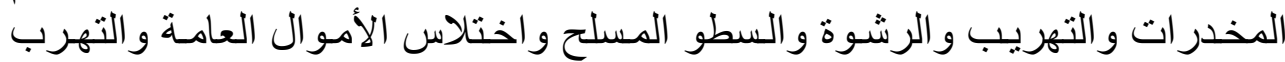

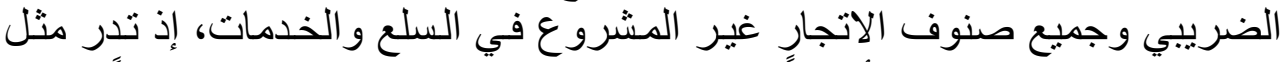

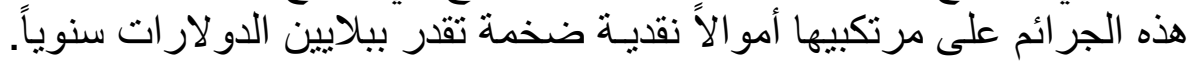

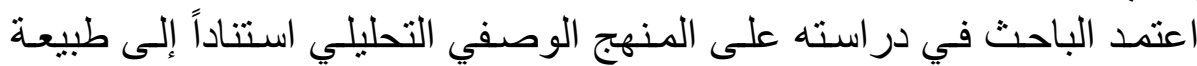

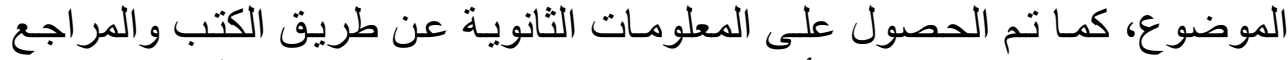

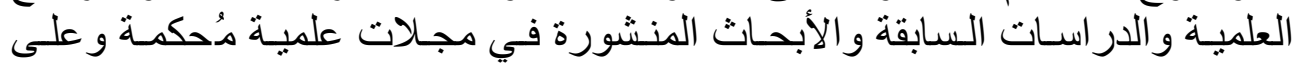




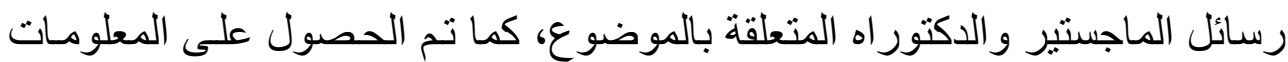

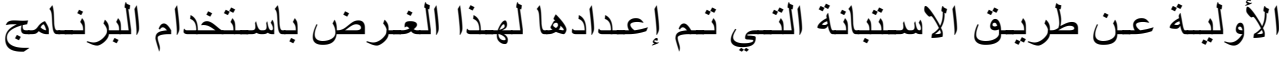

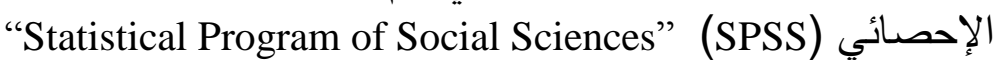
وتانكون هذه المنهجية من الآتي:

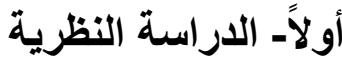

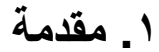

إن غسيل الأموال القذرة ليست وليدة القرن الحادي و العشرين الحالي و إنما لها

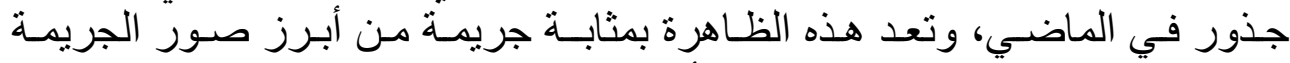

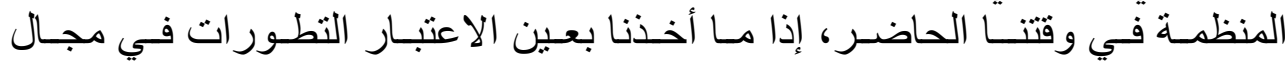

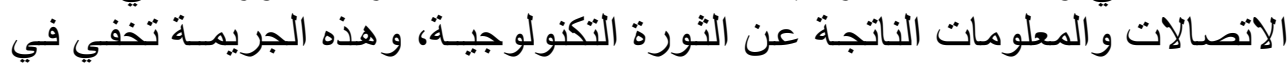

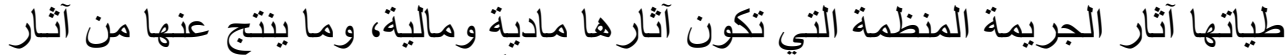

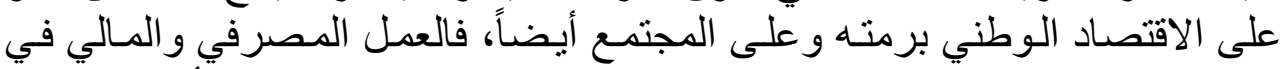

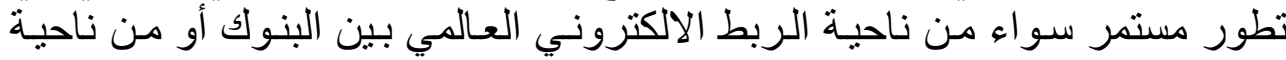

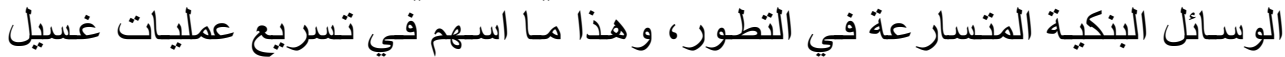

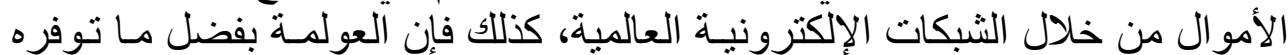

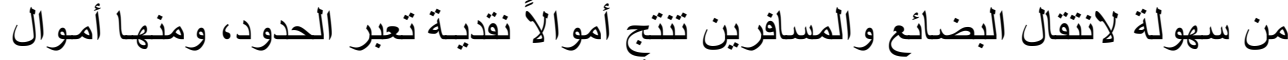

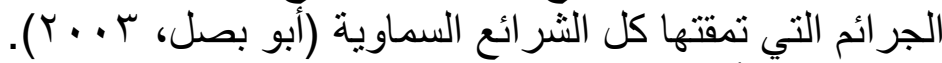
Y. مصادر الأموال القذرة (محمود، 999 (1) 1)

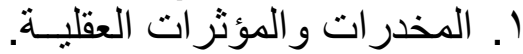

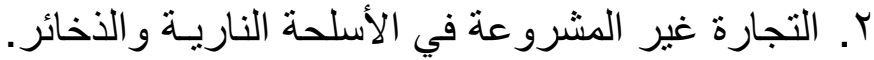

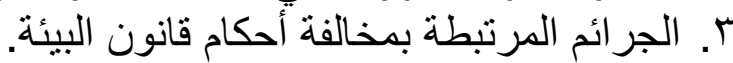
ع. الخطف و القرصنـة والإرهاب.

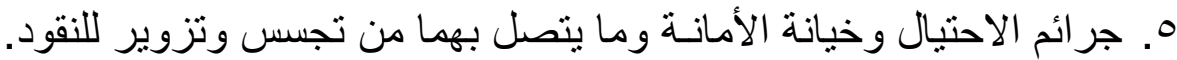

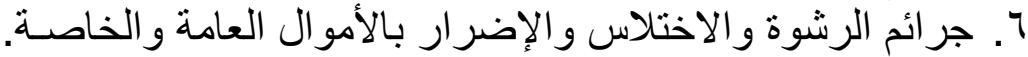

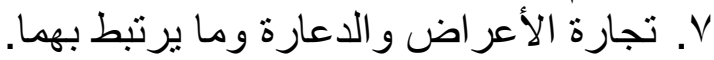

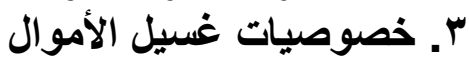

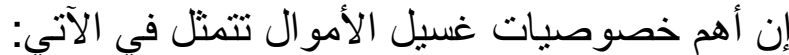

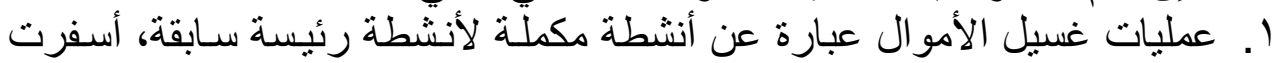

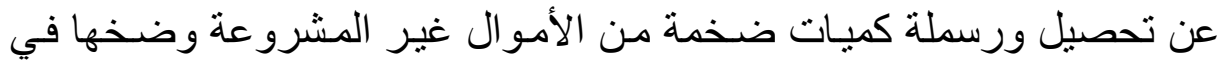

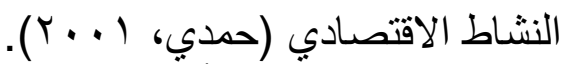

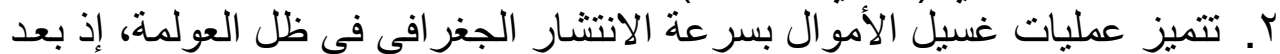

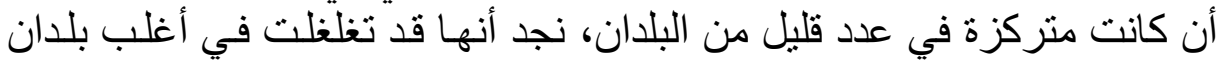

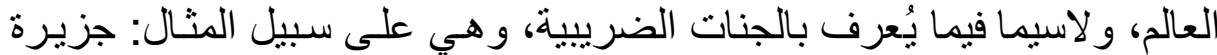

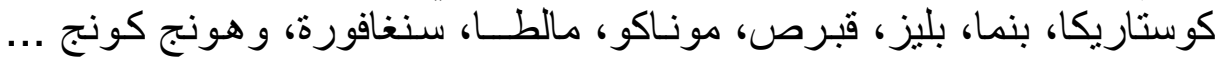
الخ.

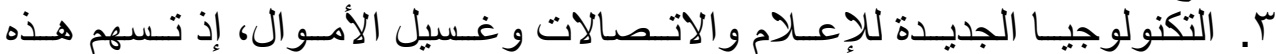

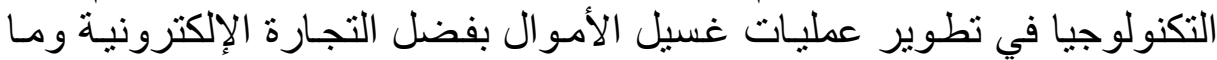




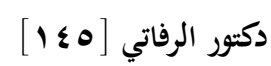

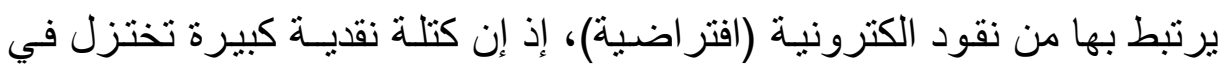

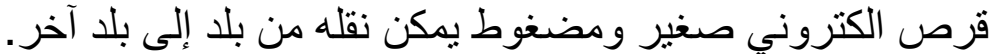

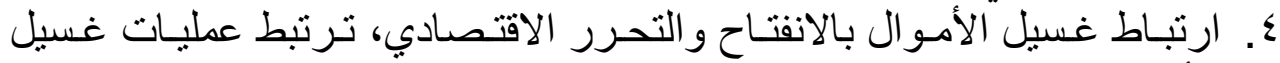

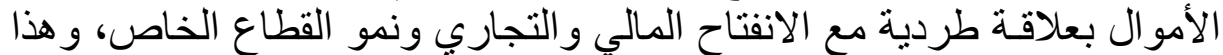

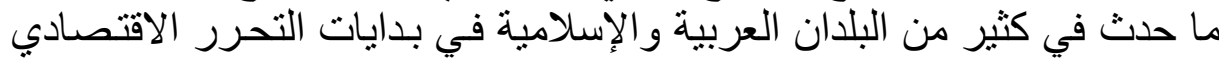

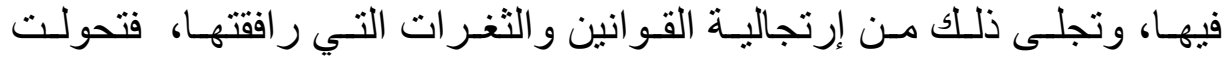

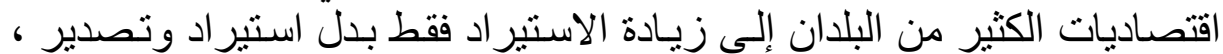

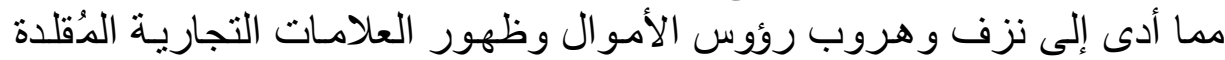

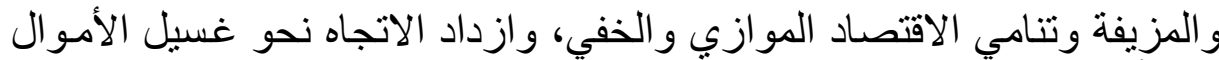

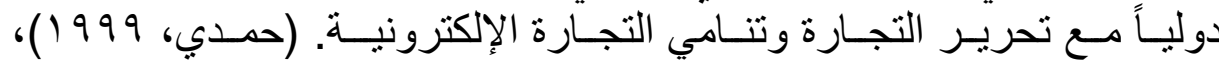
.(Henniessai, A. 1992)

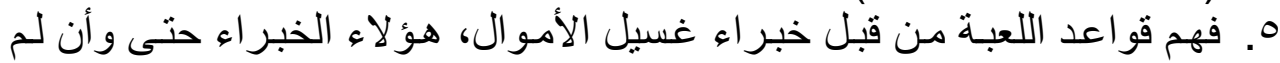

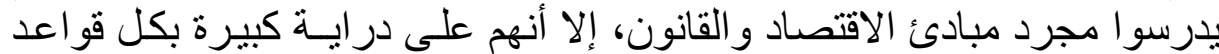
المر اقبـة و الإثر اف و الصرف و والمعاملات و والجمارك. (Anllier, J. 1994).

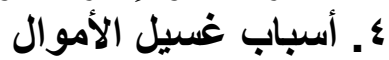

توجد العديد مـن الأسباب الكامنـة وراء تتـامي أنشطة غسيل الأمـوال، لعل

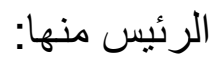

ا ـ. إنتشار التهرب الضريبي و الغش الضريبي وتفشي ظاهرة الديون المتعثرة

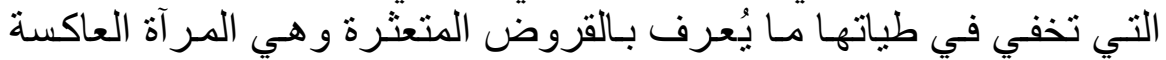

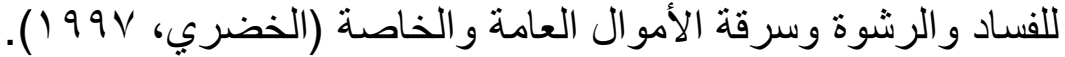

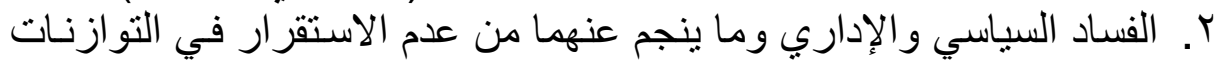

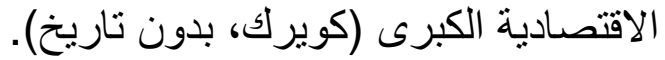

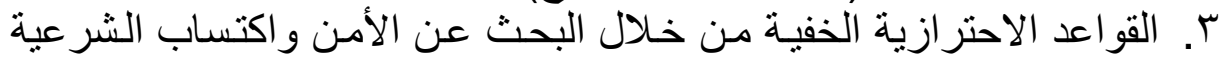

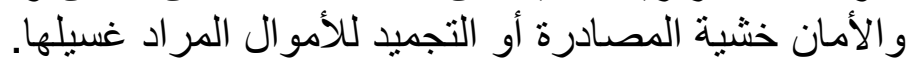

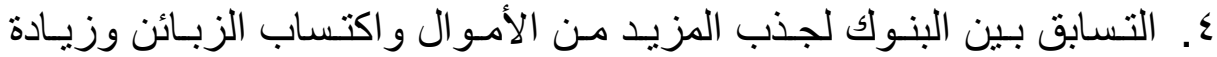

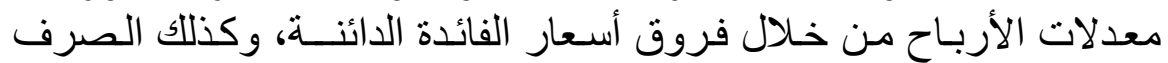

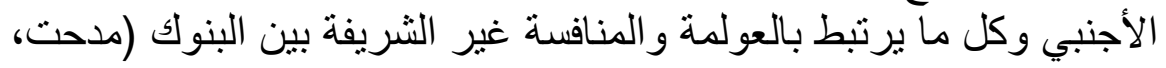
ه. الثغر ات الو اردة في تثريعات العمل و النقد و الصرف و الاستير اد و التصدير في ظل تحرير الاقتصاد.

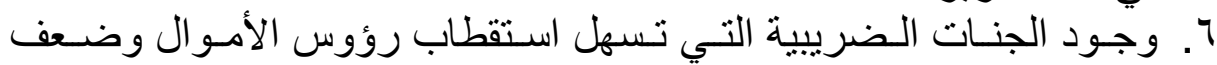
المُشنرع الوطني في صياغة القو انين. هـ الآثار المترتبـة على جزيمة غسيل الأموال

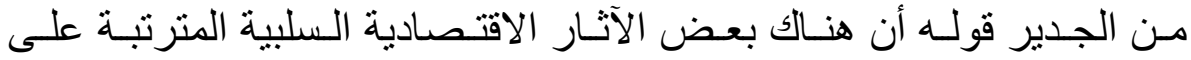

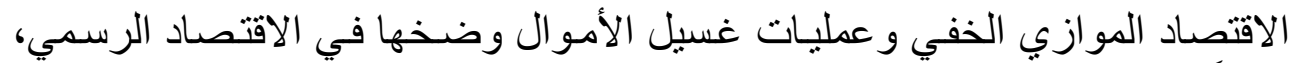

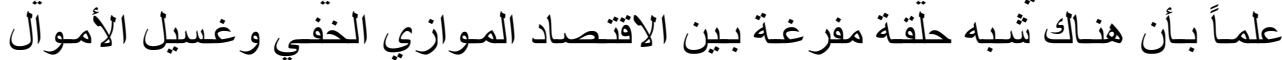
والاقتصاد الرسمي وتتجلى هذه الآثار عبر العناصر الاتيـة: 
ا. ضـرب وزعزعة الاقتصاد الوطني و الدولي و لاسيما مـا يعرف بالاقتصاد

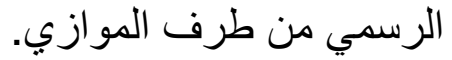
r. ضرب وتخريب المشاريع الاقتصادية الناجحة التي تمتص البطالة وتحارب

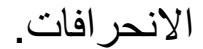

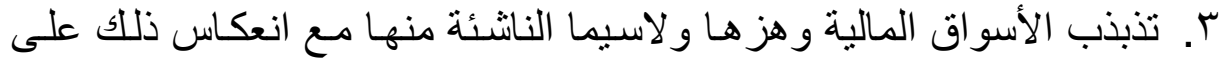

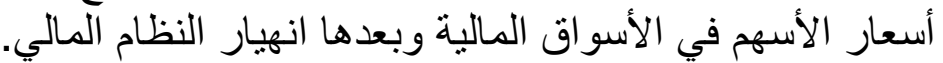

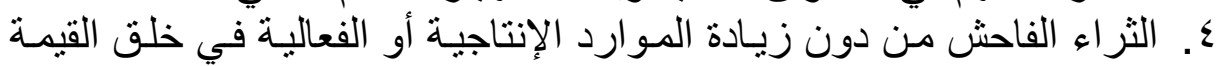
المضافة.

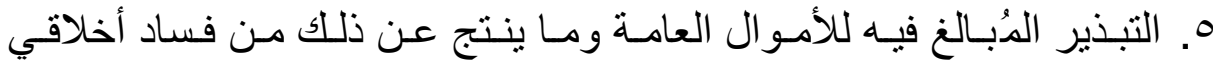
و واجتماعي و اقتصنادي. 7. علاقة غسيل الأموال بتسيير البنوك

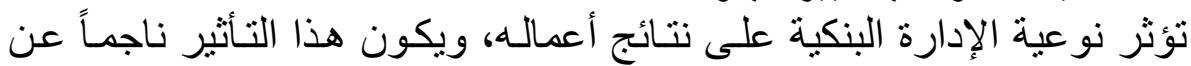

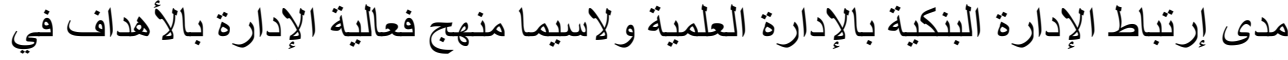

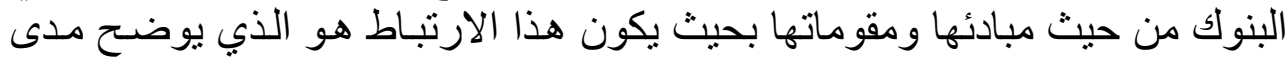

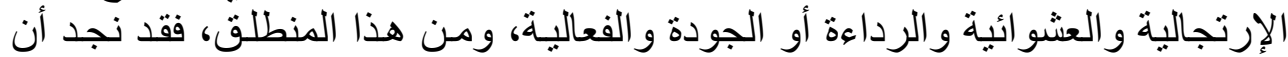

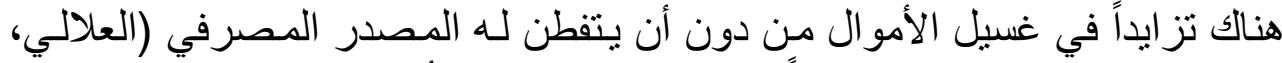

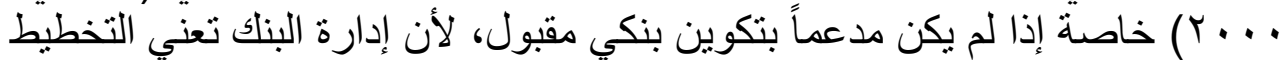

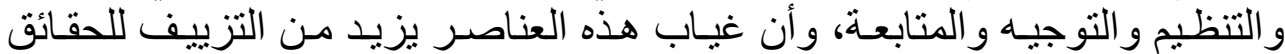

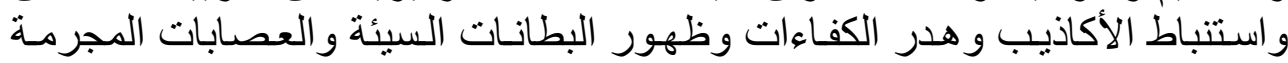

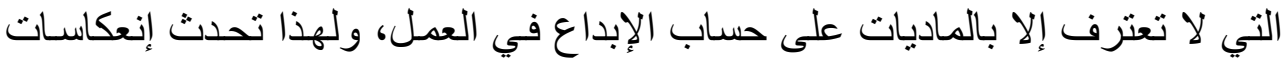

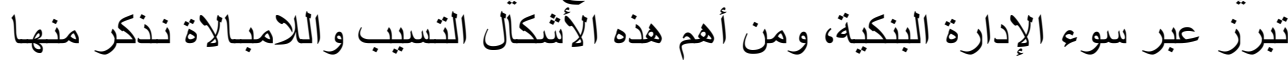

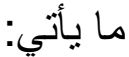

ا. إئ. سوء الإدارة الفنية الائتمانبــة.

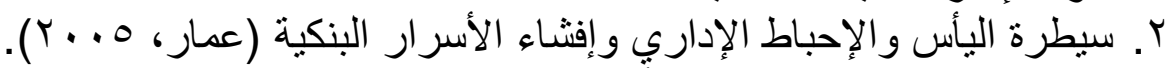

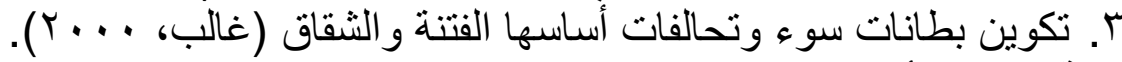

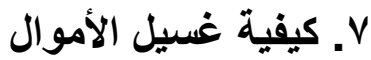
في دراسـة قام بها ج. كويك عام (1997 (19 ) يذكر جملة من الطر ائق و الوسـائل

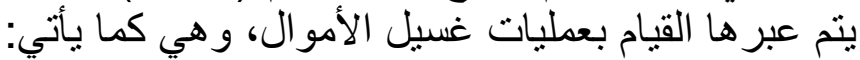

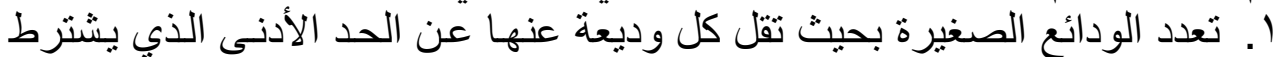
الإبلاغ عنه لزيادة التمويه.

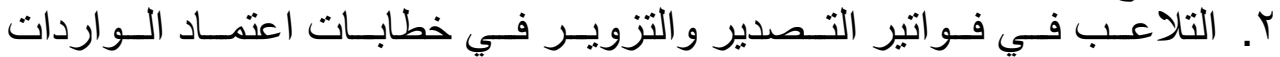

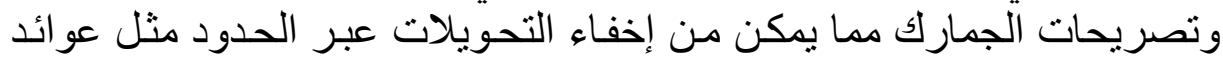

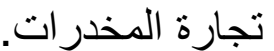

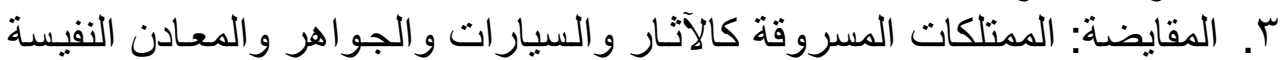

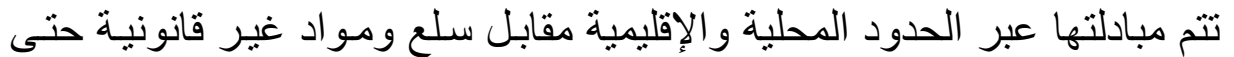
و أن كانت من نتاج القرصنة وقمع الملكية الفكرية (عبد الخالق، و 99 ( ). 


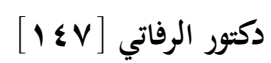

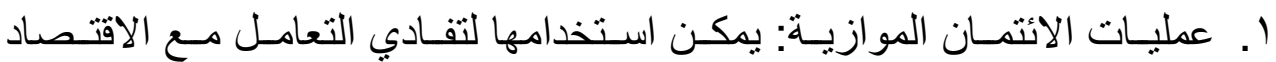

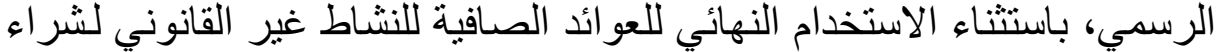

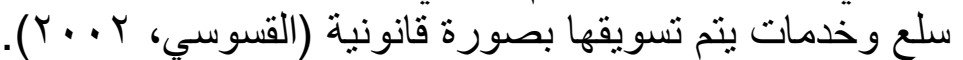

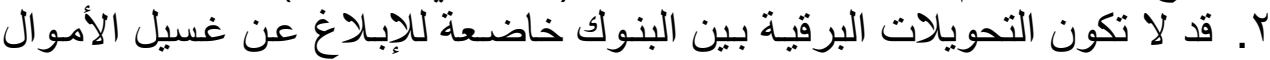

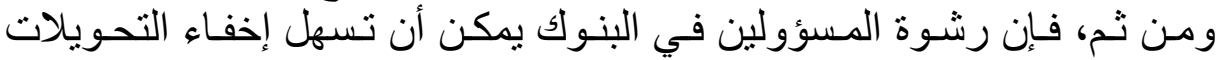

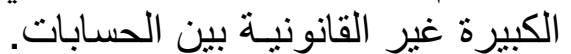

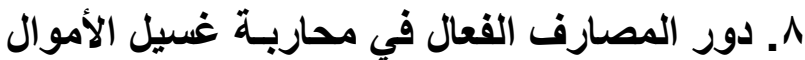

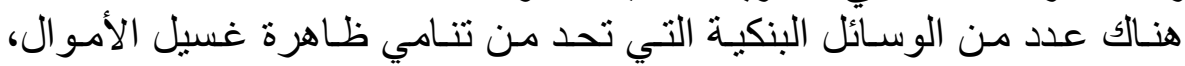
وتتمثل الإجر اءات الو اجب القيام بها بالاتي:

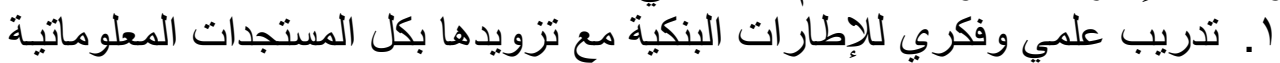

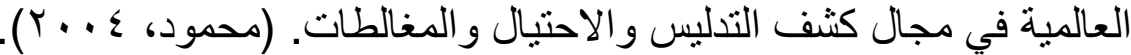

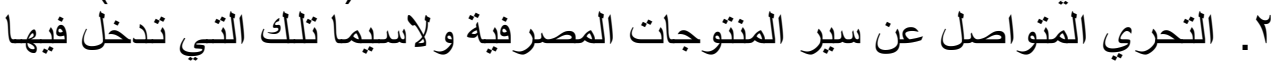

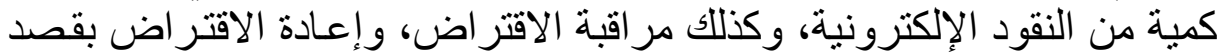

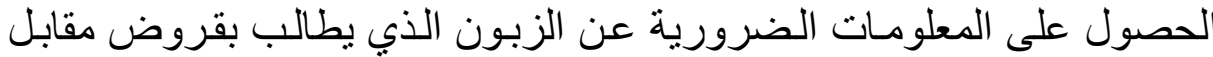

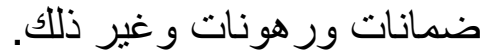

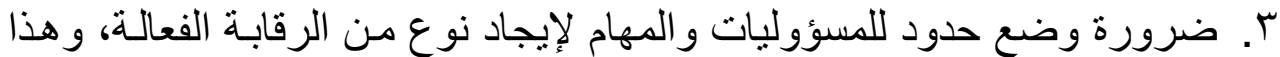

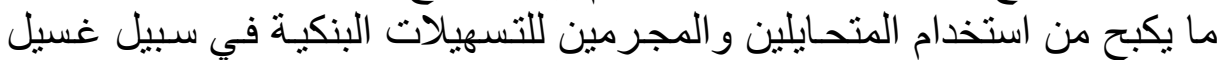

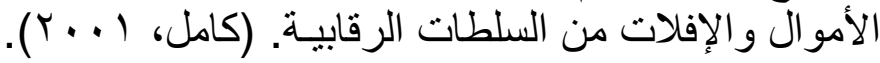

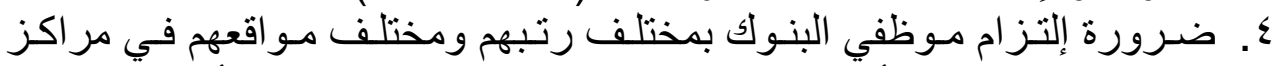
المسؤولية بالمبادئ الأساسية التي سبقت الإثـارة إليها و المتعلقة بأساليب مكافحة فركة

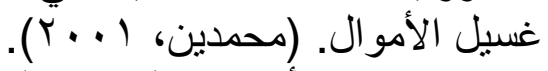

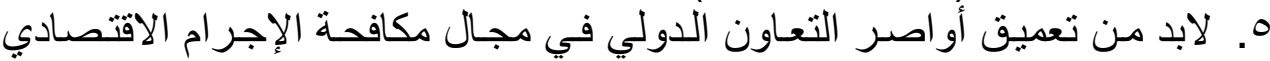
و غسيل الأموال خدمة للمجتمع الدولي والإنسانية جمعاء.

ثانياً - الاراسة الميدانية منهج الاراسـة

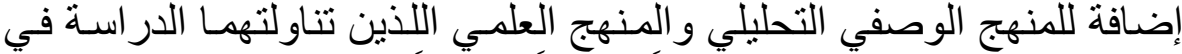

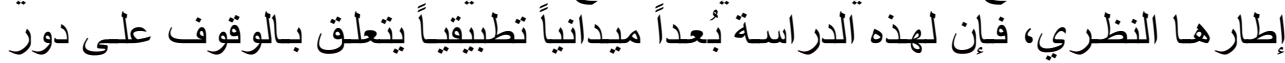

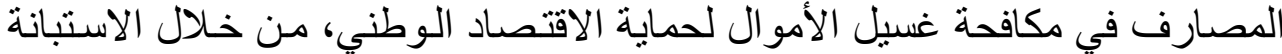
التي تم إعدادها لهذا الغرض باستخدام البرال البرناية الإحصائي (SPSS).

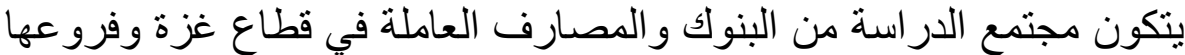

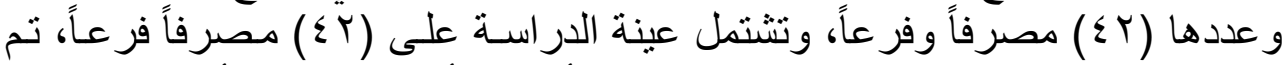

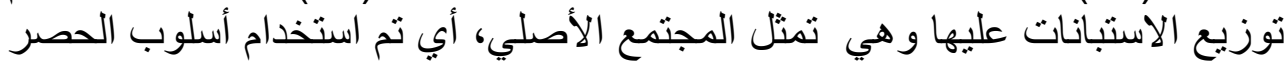

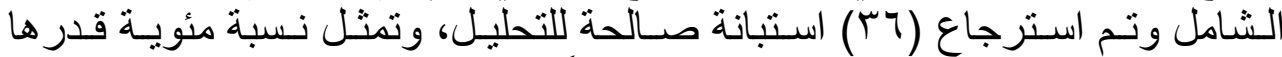

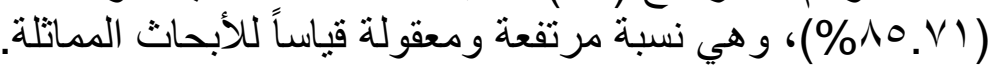




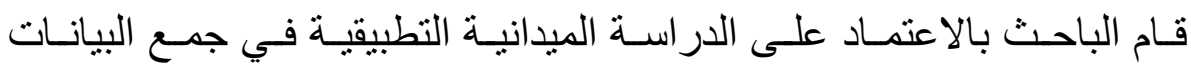

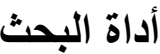

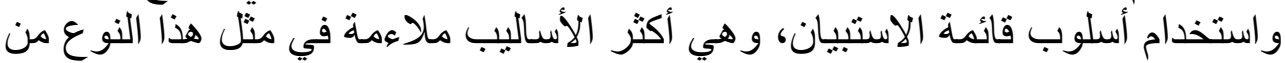

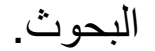

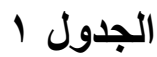

عدد الاستبانات الموزعة على البنوك والمصارف وفروعها وعدد الردود ونسبتها المئوية

\begin{tabular}{|c|c|c|c|c|}
\hline المئويبة & الردود & عدد الاستبانات الموزعة & الإيضاحات & p \\
\hline$\% \vee .1 \varepsilon$ & $r$ & $r$ & البنوك المحلية و الخارجية في قطاع غزة & 1 \\
\hline$\% \vee \wedge .0 \vee$ & rT & $r q$ & فروع البنوك المحلية و الخارجية في قطاع غزة & $r$ \\
\hline$\% \wedge \wedge . \vee 1$ & rq & $\varepsilon r$ & المجموع الكلي & \\
\hline
\end{tabular}

تم استخدام الاستبانة بوصفها إحدى أدوات الدراسة، وقد تم تقسيم الاستبانة على الأى ثلاثة مجالات بالثكل الآتي:

المجال الأول: يبين العلاقة بين توالئن افر المعلومات الكافية لدى موظفي المصارف في

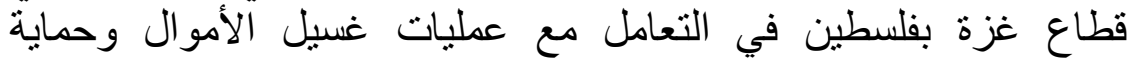

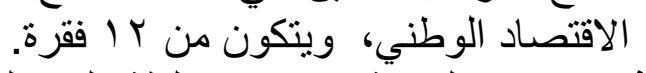

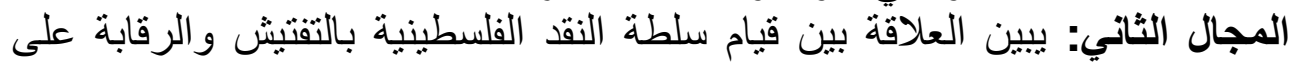

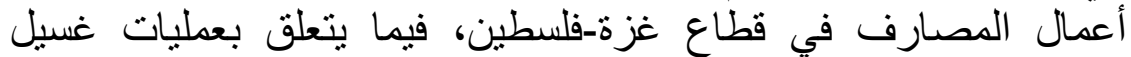

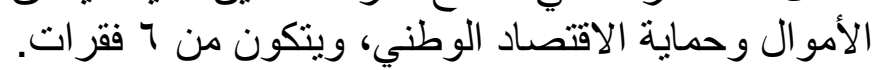

المجال الثالث: يبين العلاقة بين عدم التزام المصارف التان وسلطة النقاد الفلسطينية بمكافحة ظاهرة غسيل الأموال وبين انهيار المؤسسات المالية الماتية الناجحة

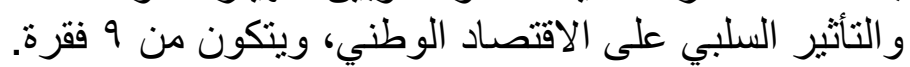

\begin{tabular}{|c|c|c|c|c|c|}
\hline غير مو افق بشدة & غير مو افق & محايد & مو افق & مو افق بشدة & التصنيف \\
\hline 1 & $r$ & r & $\varepsilon$ & 0 & النقاط \\
\hline
\end{tabular}

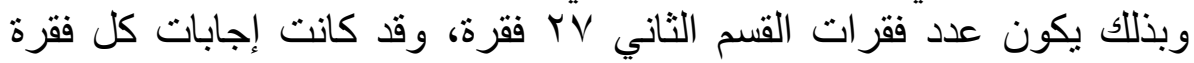

\section{صدق الاستبيان وثباتها}

قام الباحث بتقنين فقر ات الاختبار وذللك للتأكد من صدقه وثباته بالشكل الآتي: صدق فقرات الاختبار قام الباحث بالتأكد من صدق فقرات الات الاختبار بطريقتين. 


\section{دكتور الرفاتي [9 ؛}

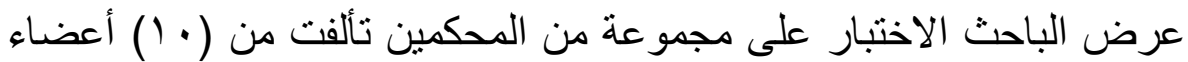

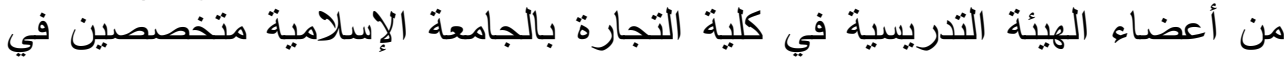

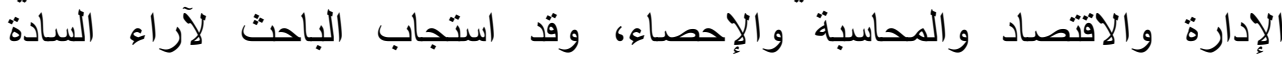

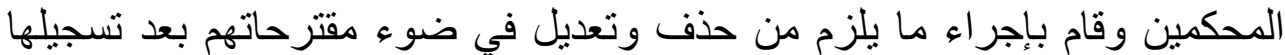

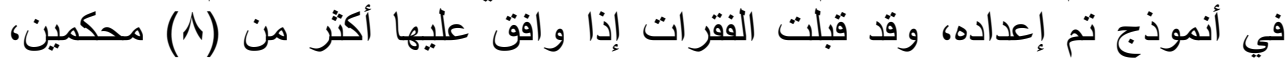

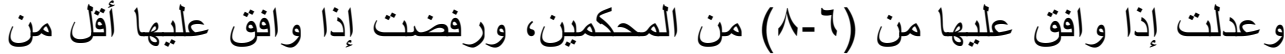
(0) محكمين، وبذللك خرج الاختبار في صورنه النهائية ليتم تطبيقه على العينة العينة

\section{r. صدق الاتساق الاخلي لفقرات الاختبار}

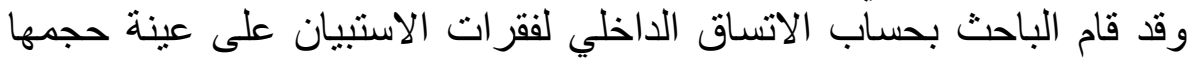

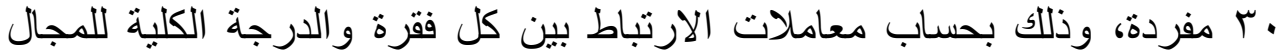

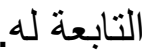

الجدول ا يبين معساملات الارتبـاط بين كل فقرة مـن فقرات المجـال الأول

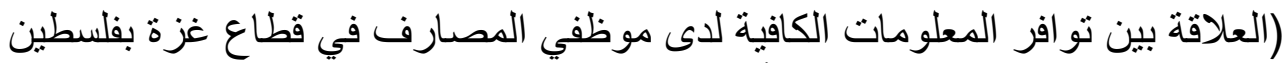

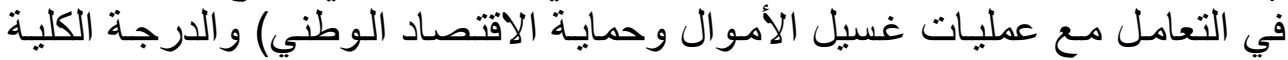

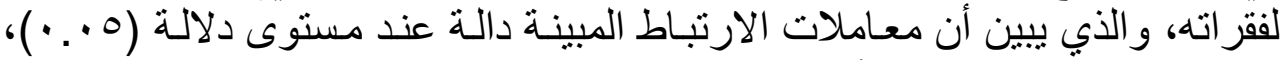
وبذلك تعد فقرات المجال الأول صادقة لما وضعت لقياسها.

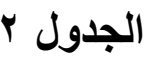

معاملات الارتباط بين كل فقرة من فقرات المجال الأول (العلاقة بين توافر

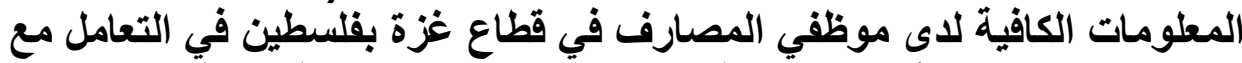

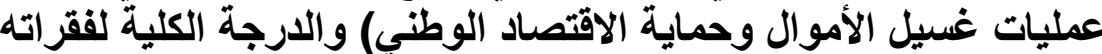

\begin{tabular}{|c|c|c|c|}
\hline 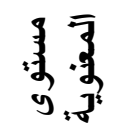 & 多穿 & محتوى الفقرة & 3 \\
\hline . & $\cdot . \varepsilon \wedge \wedge$ & 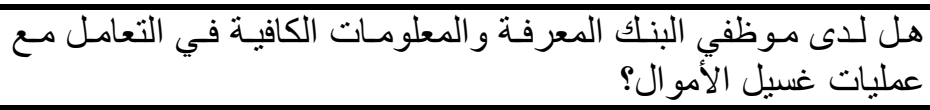 & 1 \\
\hline 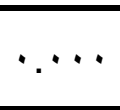 &.$V \backslash V$ & 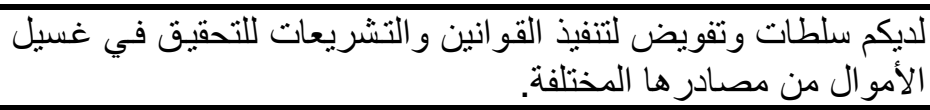 & r \\
\hline . r & $.0 Y Y$ & 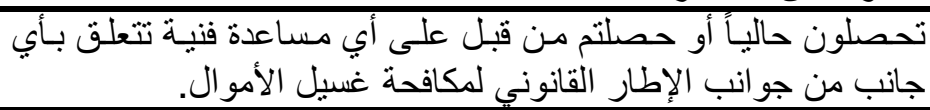 & $r$ \\
\hline &. .700 & 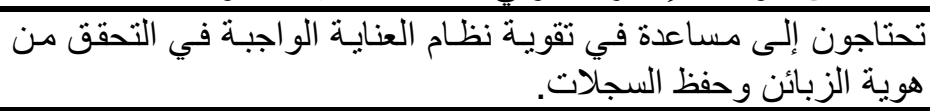 & $\varepsilon$ \\
\hline$\because \cdots 0$ & $.0 \cdots$ & تطاق اختصاصح مساعدة لتقوية إطار الإبلاغ عن المعاملات المشبوهة في & 0 \\
\hline$\because \leqslant r$ &.$\mu V \mu$ & 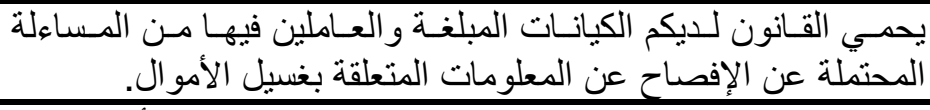 & 7 \\
\hline 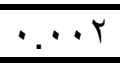 & $. .0 \leqslant \mathrm{~V}$ & يحتفظ البناك بنظم رقابة داخلية للكثف عن مصادر غسيل الأمو ال. & $\bar{v}$ \\
\hline
\end{tabular}




\begin{tabular}{|c|c|c|c|}
\hline 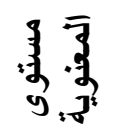 & 尔 & محتوى الفقرة & 3 \\
\hline$\because \ldots$ & $\because \leqslant 9 \vee$ & 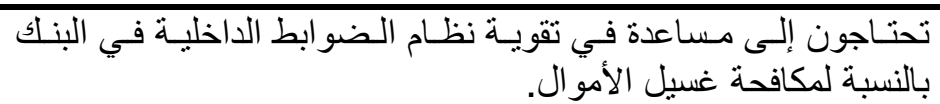 & $\wedge$ \\
\hline$\because \cdots$ & $\because \vee 9 \vee$ & 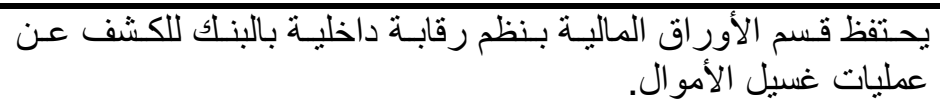 & 9 \\
\hline$\because \cdots$ & $.7 T \varepsilon$ & تعنقل الأمو أن موظف البنك لديكم بحاجة إلى تدريب على بر امج مكافحة & 1. \\
\hline$\because \cdots$ & $\because V \leq V$ & إليه الحو الة. أوامر تحويلات مالية هل يحتفظ البنك بمعلومـات لمن ترسل & 11 \\
\hline 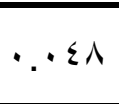 & ع זד. & 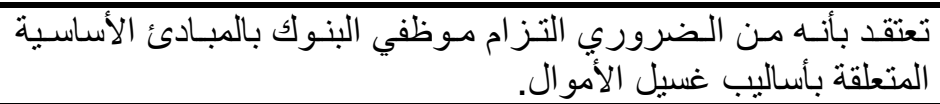 & IT \\
\hline
\end{tabular}

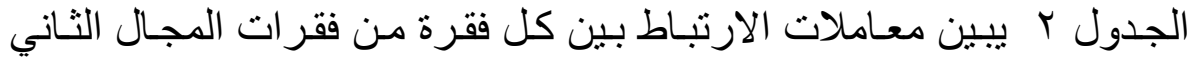

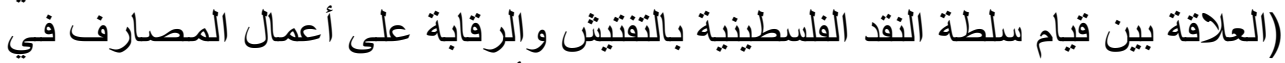

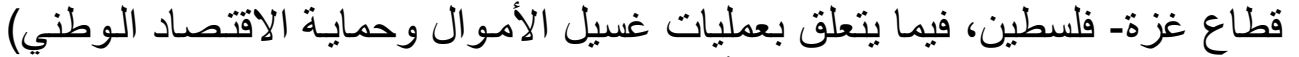

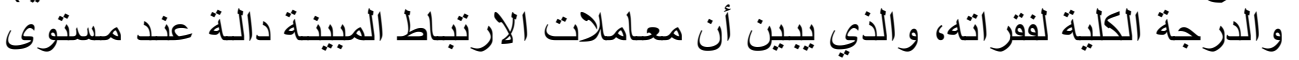

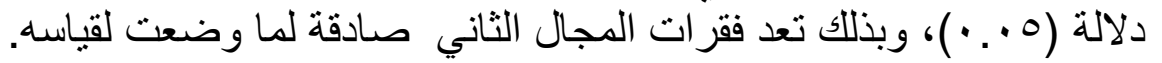

\section{الجدول بان الجي}

معاملات الارتباط بين كل فقرة من فقرات المجال الثاني (العلاقة بين قيام سلطة النقا الفلسطينية

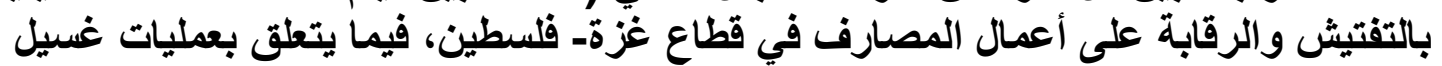
الأموال وحماية الاقتصاد ألوطني) والارجة الكلية لفقراته فيماته

\begin{tabular}{|c|c|c|c|}
\hline 事 & 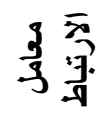 & الفقرات & 3 \\
\hline$\because \cdots$ & $\cdot \lambda \cdot \varepsilon$ & 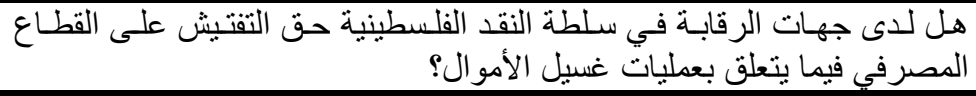 & 1 \\
\hline$\because \cdots$ & $\because V T O$ & 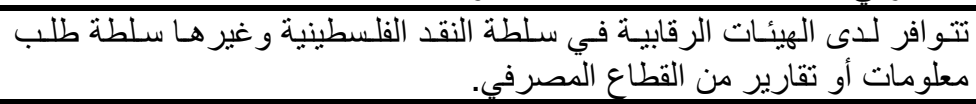 & $r$ \\
\hline • & O & 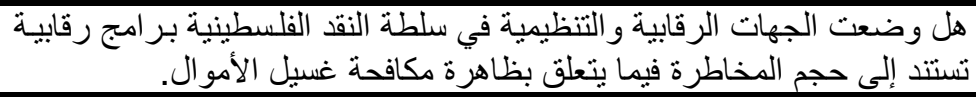 & $r$ \\
\hline$\because \cdots$ & $\cdot .7 \lambda$. & 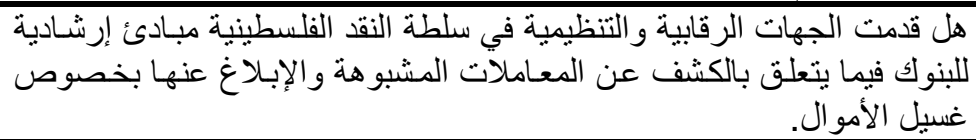 & $\varepsilon$ \\
\hline$\because \cdots$ & $\cdot T$ T & 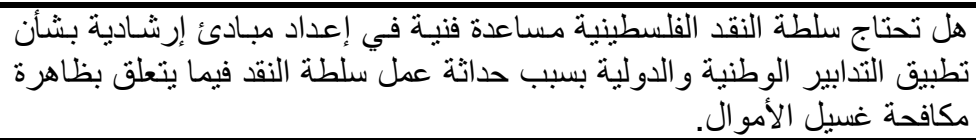 & 0 \\
\hline
\end{tabular}




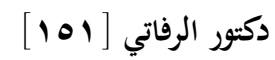

\begin{tabular}{|c|c|c|c|}
\hline 事 & 多穿 & الفقرات & 疍 \\
\hline$\because \cdots$ & $\cdot \wedge \varepsilon$. & 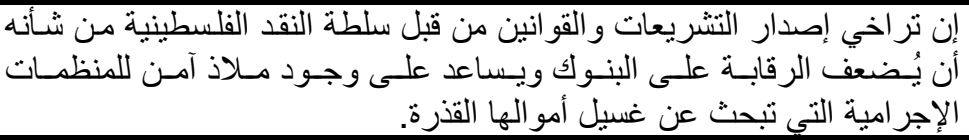 & 7 \\
\hline
\end{tabular}

الجدول r يبين معاملات الارتباط بين كل فقرة من فقرات المجال الثالث

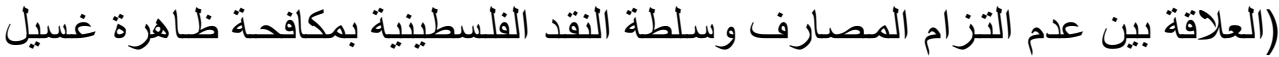

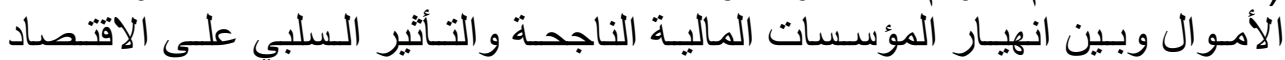

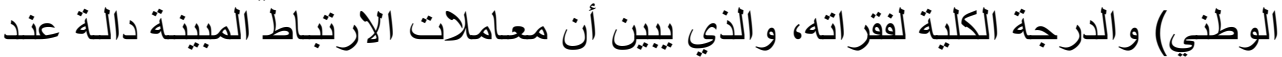
مستوى دلالة (0. . •)، وبذلك تعد فقرات المجال الثالث صلادئ صادقة لما وضعت لقاطياسه.

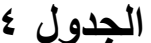

معاملات الارتباط بين كل فقرة من فقرات المجال الثالث (بين عدم التزام المصارف الثال وسلطة

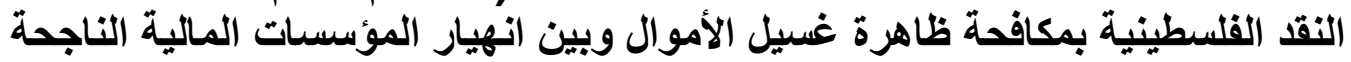

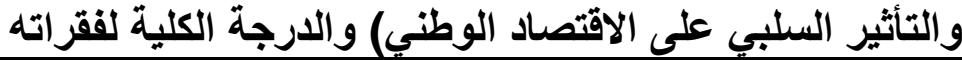

\begin{tabular}{|c|c|c|c|}
\hline 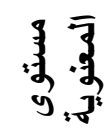 & 高竞 & محتوى الفقرة & 矛 \\
\hline & $\cdot .7 \leqslant 1$ & 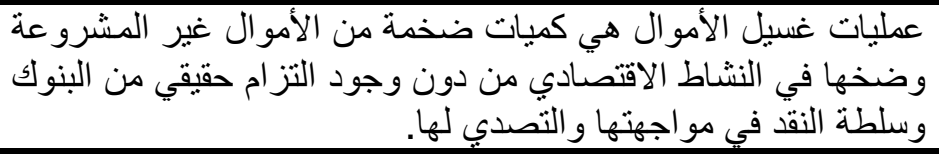 & 1 \\
\hline & $\cdot V \leqslant r$ & 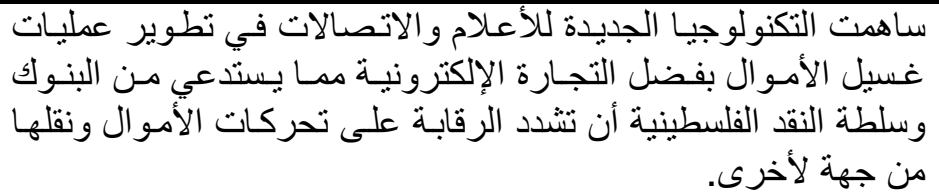 & r \\
\hline & •VOT & 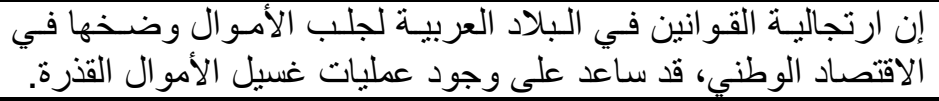 & $r$ \\
\hline & •VOT & 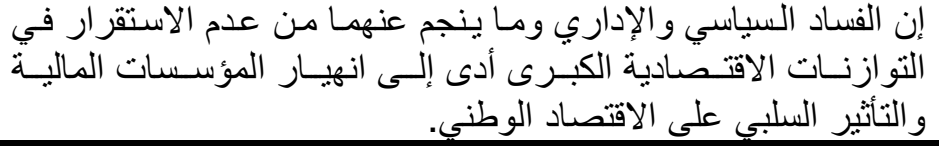 & $\varepsilon$ \\
\hline
\end{tabular}




\begin{tabular}{|c|c|c|c|}
\hline 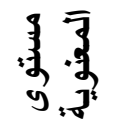 & 等羿 & محتوى الفقرة & 忽 \\
\hline$\because \cdots$ & $\because V \leqslant Y$ & 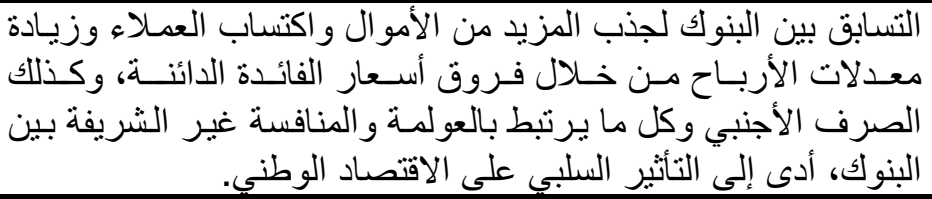 & 0 \\
\hline$\because$ & . Tr. & 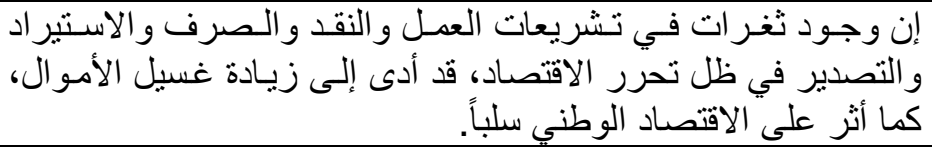 & 7 \\
\hline & $\because V \leqslant \Lambda$ & 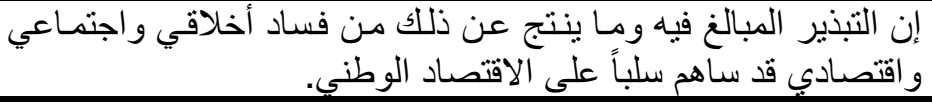 & V \\
\hline$\cdot$ & $\because \vee 17$ & 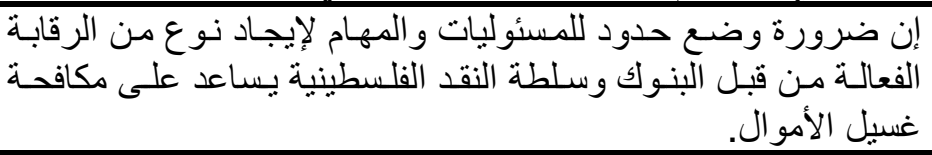 & $\Lambda$ \\
\hline$\because \cdots$ & $\because V \leqslant \Lambda$ & 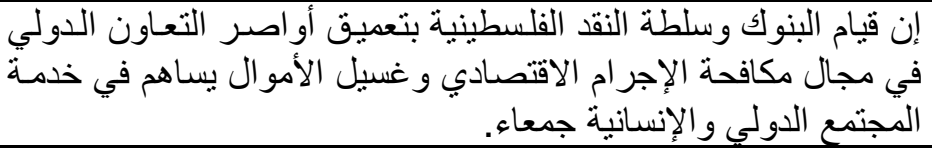 & 9 \\
\hline
\end{tabular}

\section{Reliability تُبات الاستبانة}

وقد أجرى الباحث خطوات الثبات النهات على العينـة الاستطلاعية نفسها بطريقتين هما طريقة التجزئة النصفية ومعامل ألفا كرونباخ.

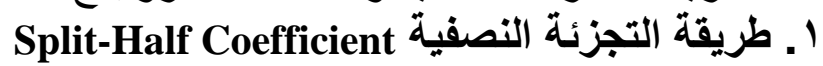

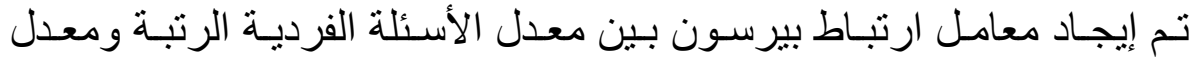

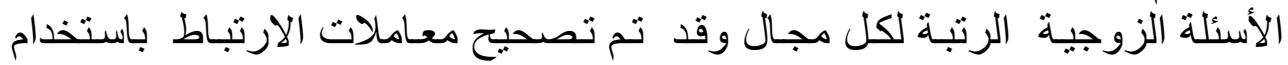

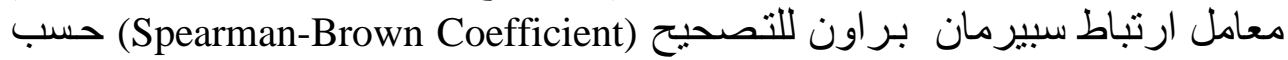

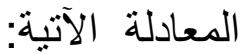

معامل الثبات = هناك معامل ثبات كبير نسبيا لفقر ات الاستبيان.

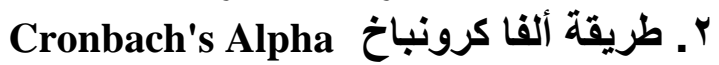

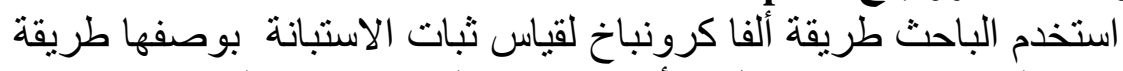

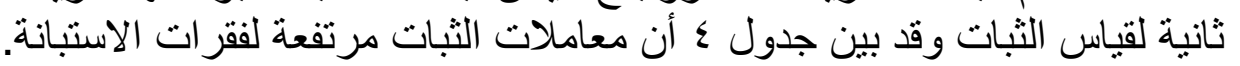




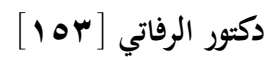

معامل الثبات (طريقة التجزئة النصفية والفا كرونباخ)

\begin{tabular}{|c|c|c|c|c|c|}
\hline \multirow{2}{*}{ طريقة الفاخ } & \multicolumn{3}{|c|}{ طريقة التجزئة النصفية } & \multirow[b]{2}{*}{ الفقرات } & \multirow[b]{2}{*}{ المجال } \\
\hline & المعنوية & معامل الارتباط & الارتباط معامل & & \\
\hline.$\vee \vee 9 \wedge 0$ & $\because \cdots$ & $\cdot \Lambda I Y V$ & $.7 \wedge \leqslant 0$ & IT & الأول \\
\hline $.9 Y 0 \leqslant$ & $\because \cdots$ & $.919 V$ & $. \wedge 01 \leqslant$ & 7 & الثاني \\
\hline $.91 \vee \leqslant$ & $\because \cdots$ & $.91 \cdot \varepsilon$ &.$\wedge T 00$ & 9 & الثالث \\
\hline
\end{tabular}

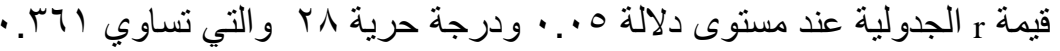

\section{المعالجات الإحصائية}

لقد قام الباحث بتفريغ وتحليل الاستبانة من خلال برنامج SPSS الإحصائي وتم استخدام الاختبار ات الإحصائية الآتية:

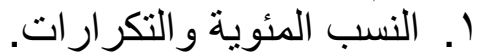

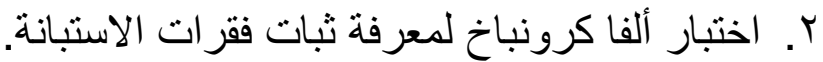
ז. معامل ارتباط بيرسون لقياس صدق الفقر ات.

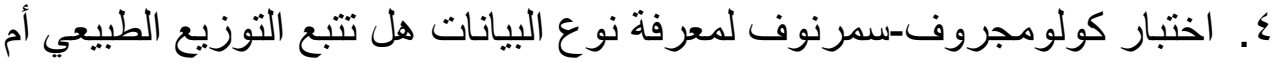
.(1-Sample K-S) ل

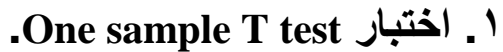

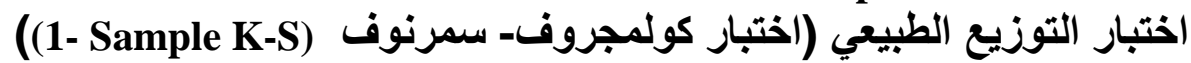

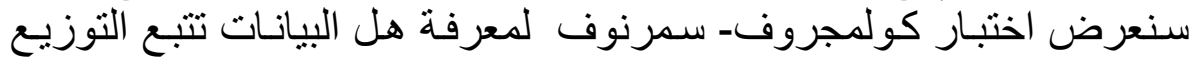

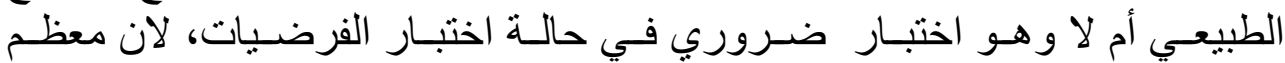

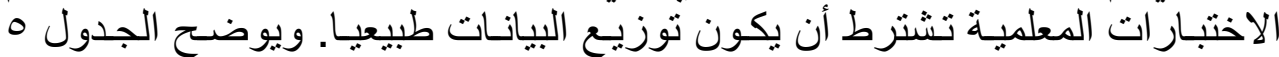

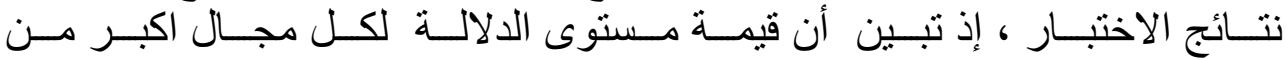

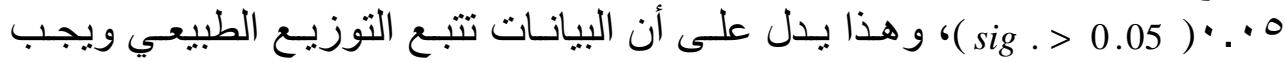
استخدام الاختبار ات المعلمية.

\section{الجدول}

اختبار التوزيع الطبيعي( One-Sample K-S)

\begin{tabular}{|c|c|c|}
\hline مستوى المعنوية & قيمة الاختبار Z & المجال \\
\hline$\because \vee \vee 7$ & $1 . Y V V$ & الأول \\
\hline$\cdot . \varepsilon \cdot 1$ &.$\wedge \wedge 9$ & الثاني \\
\hline.$V \cdot 7$ &..$V \cdot r$ & الثالث \\
\hline - TVA &. .911 & جميع المجالات \\
\hline
\end{tabular}




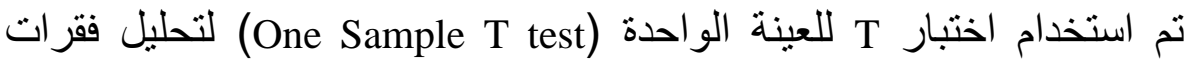

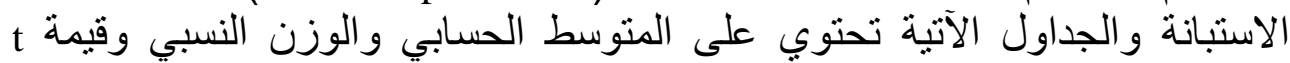

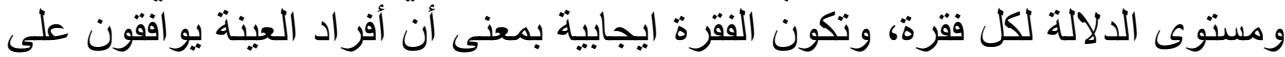

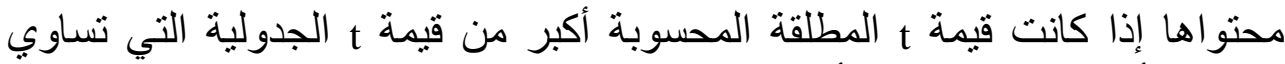

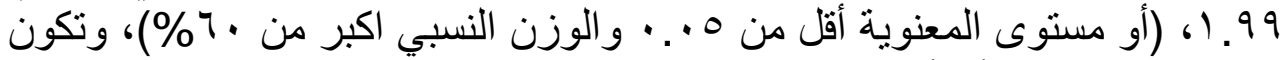

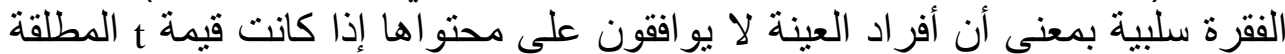

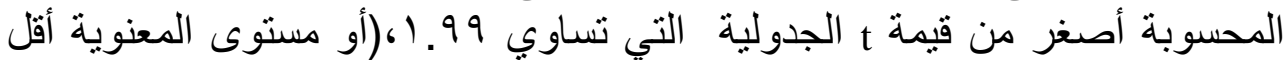

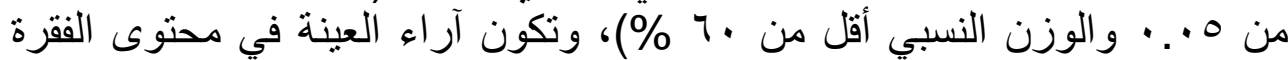
محايدة إذا كانت قيمة مستوى المعنوية أكبر 0. .

"لا توجد علاقة عند مستوى دلالة إحصائية ه . . • بين توافر المعلومات الكافية

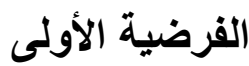

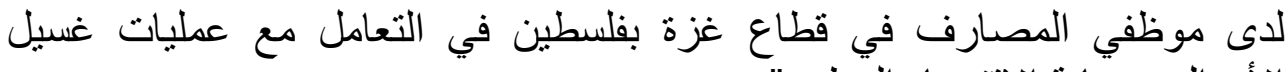
الأمو ال وحماية الاقتصاد الوطني".

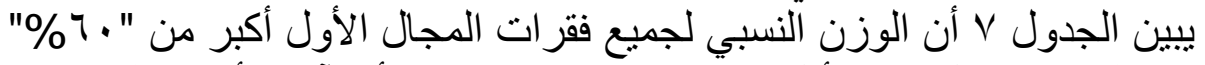

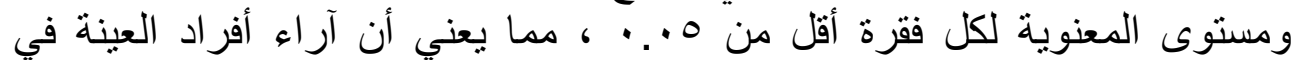

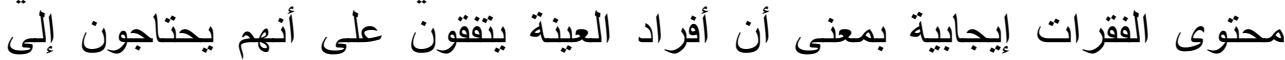

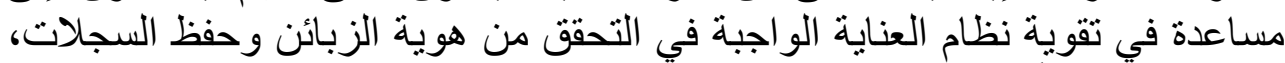

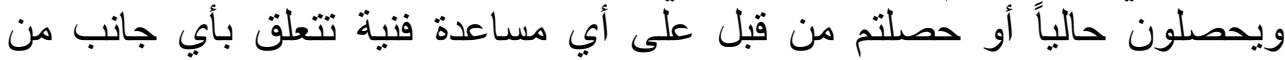

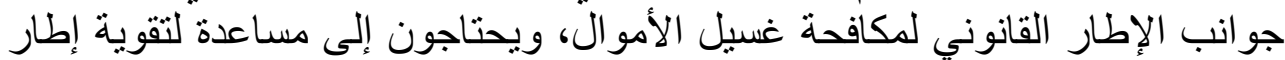

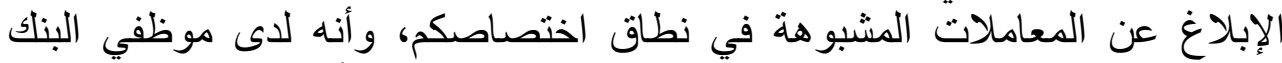

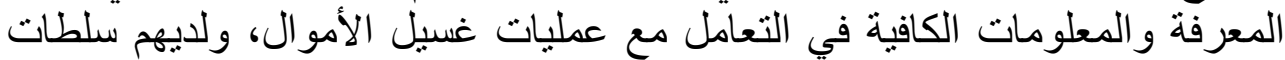

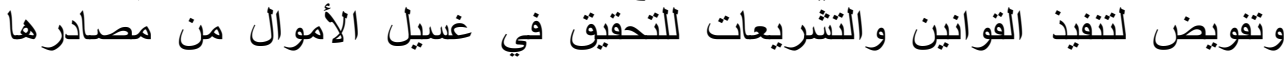

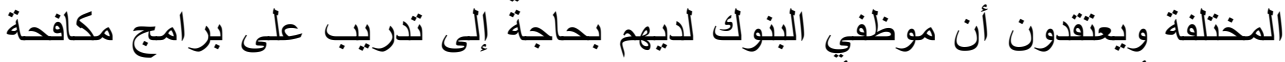

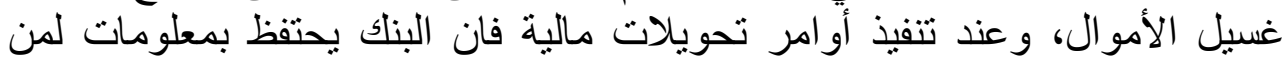

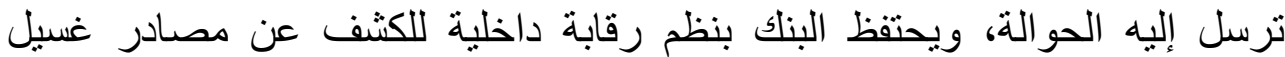

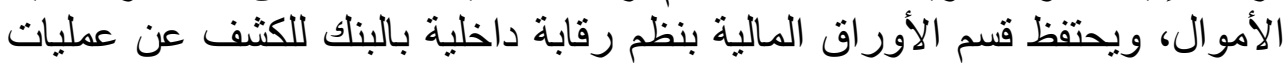

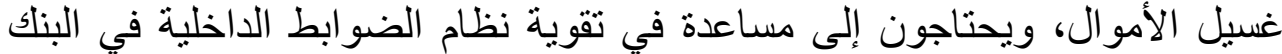

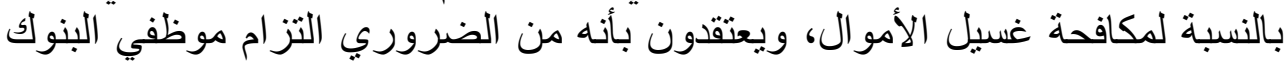

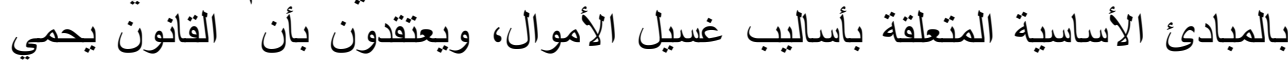

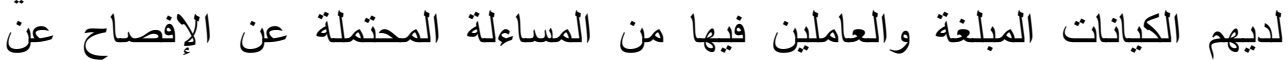
المعلومات المتعلقة بغسيل الأمو ال. المان.

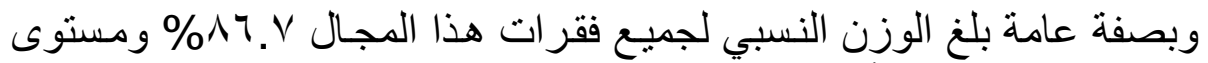

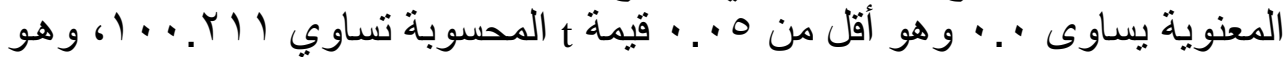

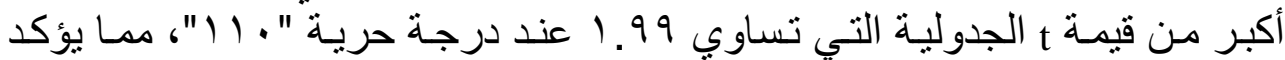

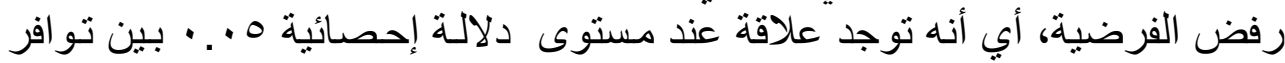




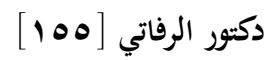

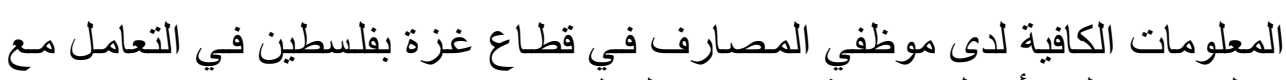
عمليات غسيل الأمو ال وحماية الاقتصاد الوطني.

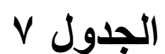

نتائج فقرات المجال الأول (العلاقة بين توافر المعلومات الكافية لاى موظفي المصارف في قطاع غزة بفلسطين في التعامل مع عمليات غسيل الأموال وحماية الاقتصاد الوطني)

\begin{tabular}{|c|c|c|c|c|c|c|}
\hline 牙: & 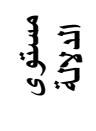 & :98. & 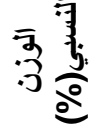 & 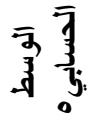 & الفقرات & 3 \\
\hline r & $\because \cdots$ & Tะ. & 94.1 & $\varepsilon .7$. & 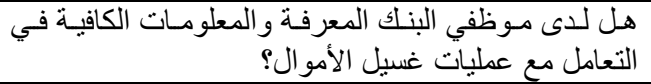 & 1 \\
\hline$\varepsilon$ & $\because \cdots$ & T1.07. & $9 \cdot .1$ & $\varepsilon .0$. & 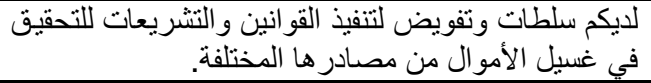 & $r$ \\
\hline r & $\ddots$ & $r q . \cdot v 1$ & $9 \leq .1$ & $\varepsilon . V$. & 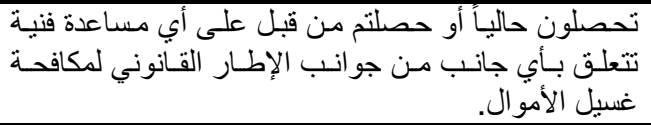 & r \\
\hline 1 & $\because \cdots$ & $\varepsilon V . \leqslant .0$ & 97. & $\varepsilon . \wedge$. & 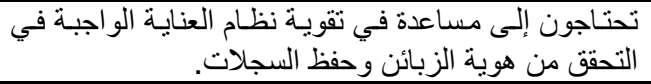 & $\varepsilon$ \\
\hline r & $\cdot$ & rV.qAᄉ & $9 \leq .1$ & $\varepsilon . \vee$. & تحتاجون إلى مساعدة لتقوية إطـار الإبـلاغ عن المعاملات & 0 \\
\hline 1. & $\because \cdots 1$ & $r . \leqslant \vee q$ & $7 \varepsilon$. & r.r. & 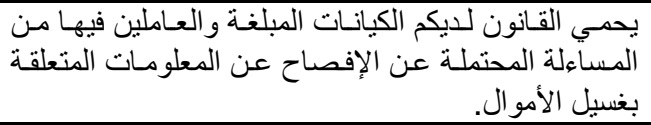 & 7 \\
\hline 7 & $\cdots$ & หq.VTA & 10.9 & $\varepsilon . \Gamma$. & الأمتوال. البنك بنظم رقابة داخلية للكثف عن مصادر غسيل & $v$ \\
\hline$\wedge$ & $\because \cdots$ & YI.0. & $\Delta r_{.} \cdot$ & ะ.1. & 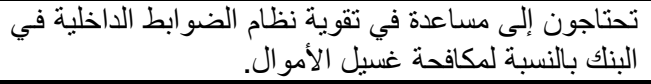 & $\wedge$ \\
\hline$\checkmark$ & $\because \cdots$ & $r 1 . r q$ & $\wedge \varepsilon$. & $\varepsilon . r_{\text {. }}$ & 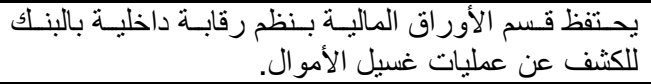 & 9 \\
\hline$\varepsilon$ & * & rT.OV. & $9 \cdot .1$ & $\varepsilon .0$. & 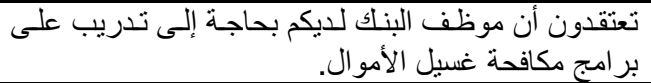 & 1. \\
\hline 0 & $\because \cdots$ & YI. rvq & 17.1 & $\varepsilon . M$ & لمن ترسن تنفي أوامر تحويلات مالية هل يحتفظ البنك بمعلومات & 11 \\
\hline 9 & & r. $0 .$. & $\wedge r_{.} \cdot$ & ะ.1. & 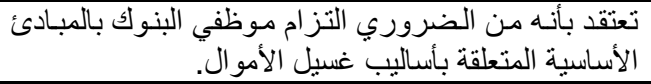 & IT \\
\hline & $\because \cdots$ & $1 \ldots Y 11$ & $\wedge \neg . \vee$ & $\varepsilon . \mu r$ & جميع فقرات المجال & \\
\hline
\end{tabular}

قيمة t الجدولية عند درجة حرية ( · (1) ومستوى معنوية 0. . . . تساوي 99.

الفرضية الثانية

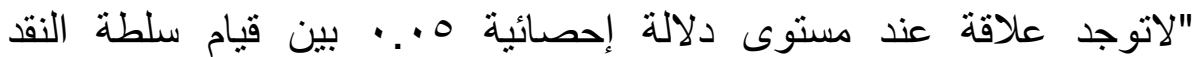

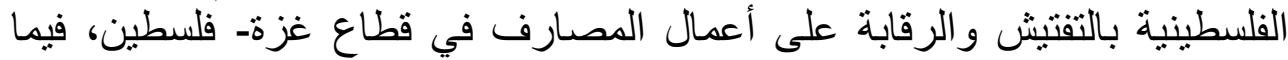
يتعلق بعمليات غسيل الأموال وحماية الاقتصاد التهالة الوطني". 
يبين الجدول ^ أن آراء أفراد العينة في جميع محتويات فقرات هذا المجال

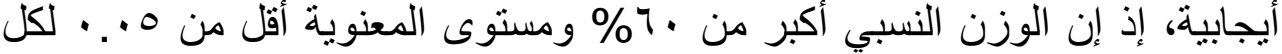

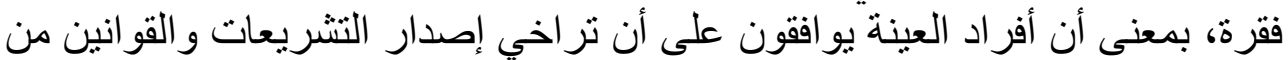

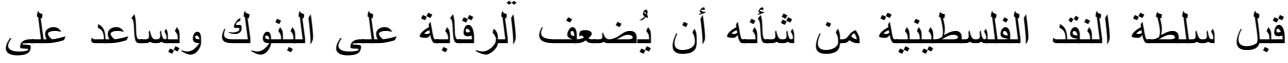

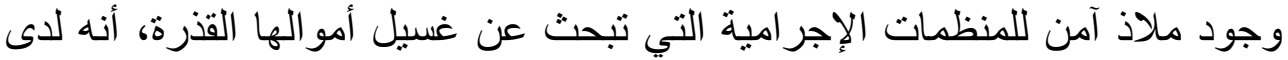

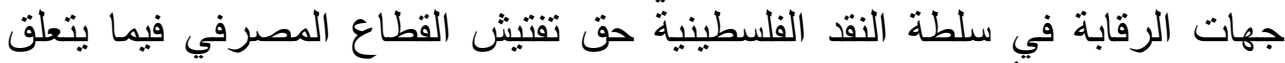

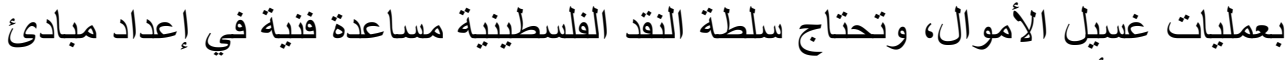

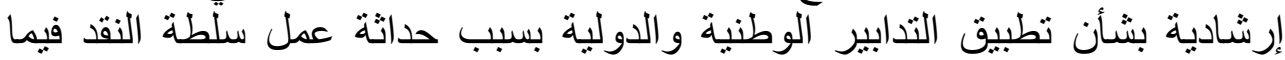

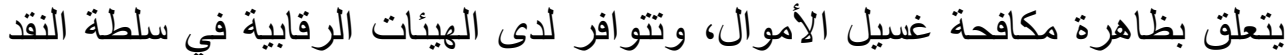

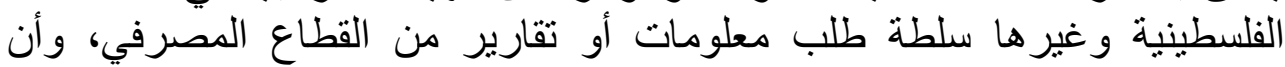

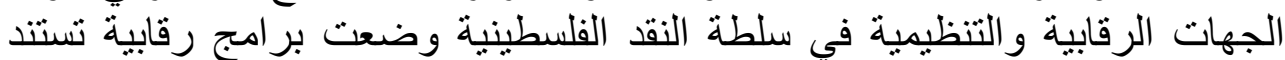

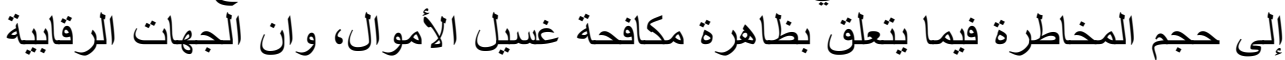

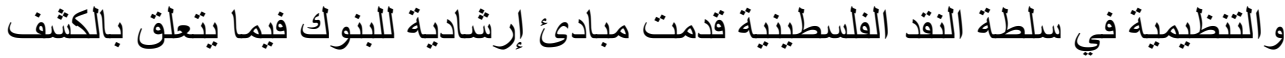

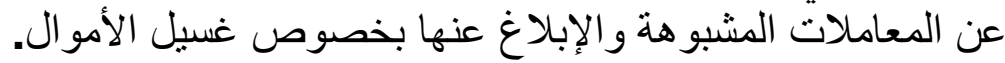

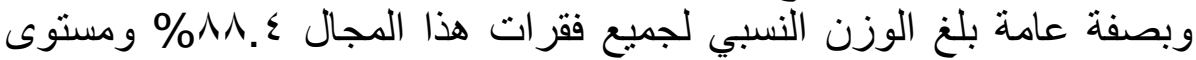

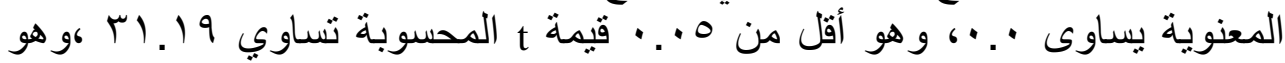

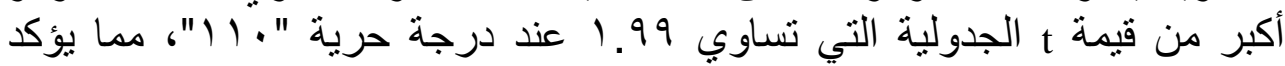

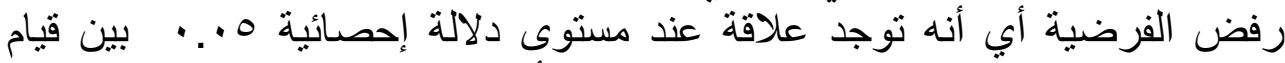

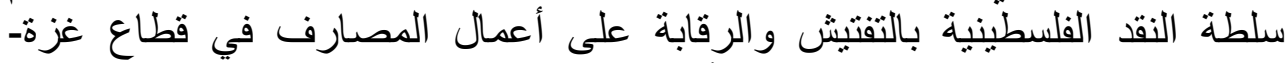
فلسطين، فيما يتعلق بعمليات غسيل الأمو ال وحماية الاقتصاد الوطني. الوطي.

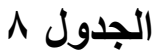

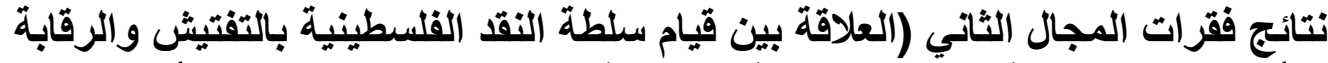
أعمال المصارف في قطاع غزة ـ فلسطين، فيما يتعلق بعمليات غسيل الأموال وحماية العاية

\begin{tabular}{|c|c|c|c|c|c|c|}
\hline \\
\hline 高 & 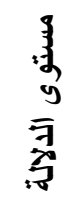 & 喡 & $\begin{array}{l}\overline{3} \\
\overline{3} \\
\overline{7} \\
\text { j. }\end{array}$ & $\overline{\frac{3}{3}}$ & الفقرات & $\frac{3}{3}$ \\
\hline r & $\because \cdots$ & rT.Or. & $9 . .1$ & ๕.०. & 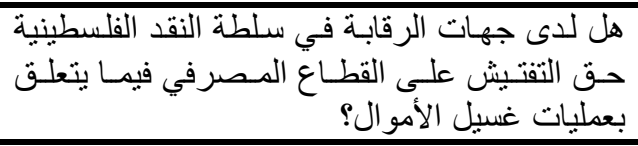 & 1 \\
\hline$\varepsilon$ & . & $r .1 \leqslant r$ & NV. 9 & $\varepsilon . \varepsilon$ & 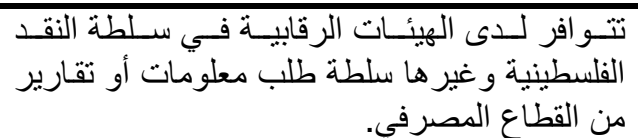 & r \\
\hline 0 & $\because \cdot$ & $r) . r \vee q$ & 1.. 1 & ¿.r & 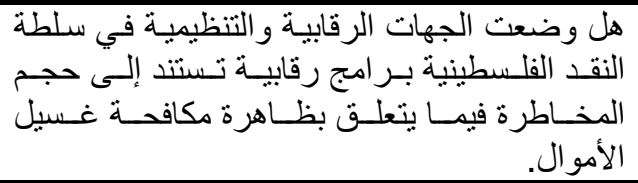 & $r$ \\
\hline
\end{tabular}




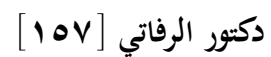

\begin{tabular}{|c|c|c|c|c|c|c|}
\hline 哥 & 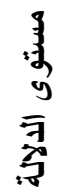 & " & $\begin{array}{l}\overline{3} \\
: 3 \\
\overline{7} \\
3 .\end{array}$ & $\overline{\bar{a}}$ & الفقرات & 预 \\
\hline 7 & $\because \cdots$ & rI.rTo & 10.9 & $\varepsilon . r$. & 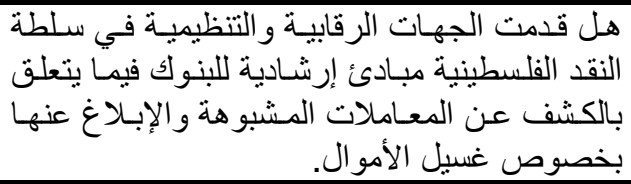 & $\varepsilon$ \\
\hline$r$ & $\because \cdots$ & YY. Y $\varepsilon$. & $\wedge \Lambda .1$ & $\varepsilon . \varepsilon 1$ & 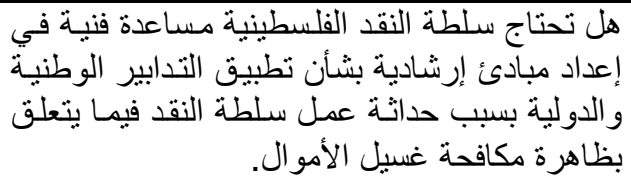 & 0 \\
\hline 1 & $\because \cdots$ & $r_{0} \leqslant r_{q}$ & 9Y. & $\varepsilon .7$. & 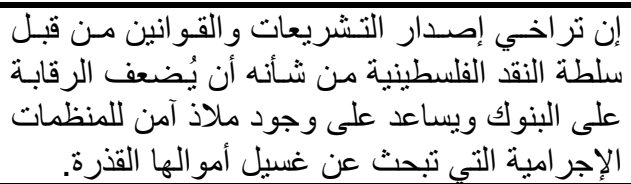 & 7 \\
\hline & 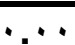 & 41.19. & $\Lambda \wedge . \varepsilon$ & 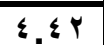 & جميع فقرات المجال & \\
\hline
\end{tabular}

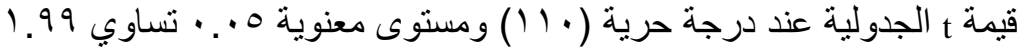

الفرضية الثالثة

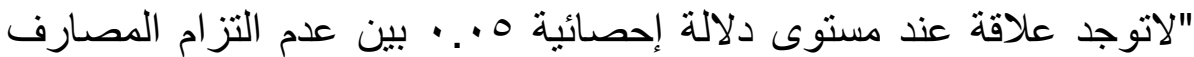

وسلطة النقد الفلسطينية بمكافحة ظاهرة غسيل الأموال وبين الهين انهيار المؤسسات المالية الماتية

الناجحة والتأثنير السلبي على الاقتصاد الوطني".

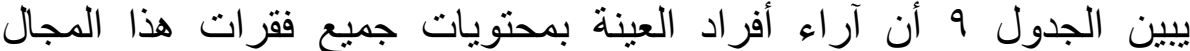

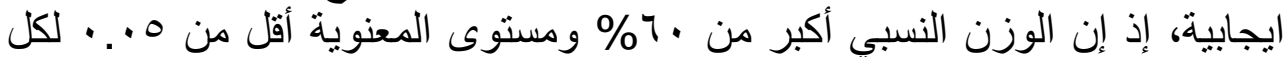

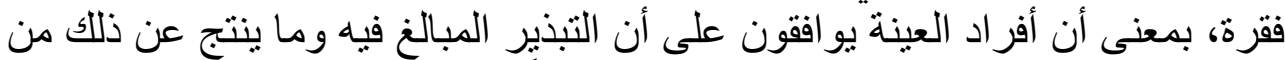

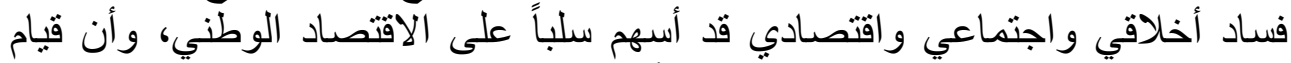
البنوك وسلطة النقد الفلسطينية بتعميق أواصر التعائ التعاون الدولي في مجال مكافحة الإنة

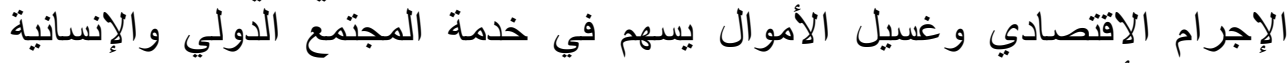

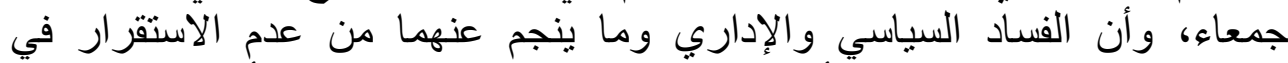

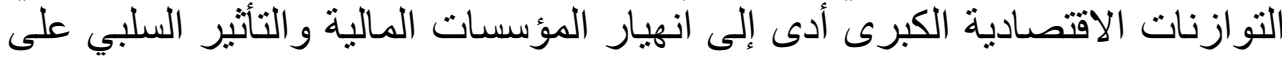

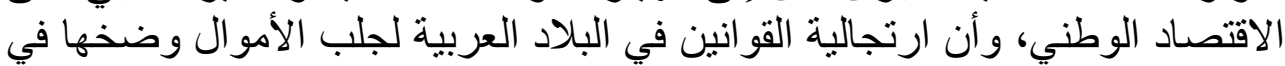

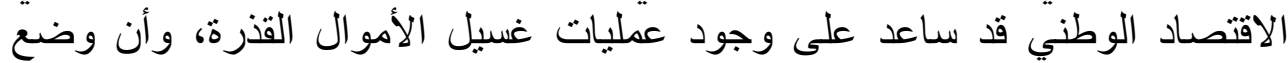

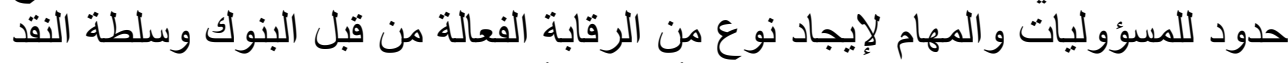

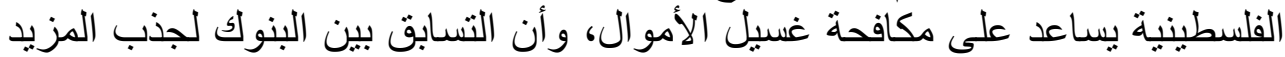

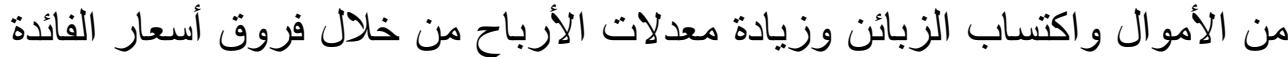

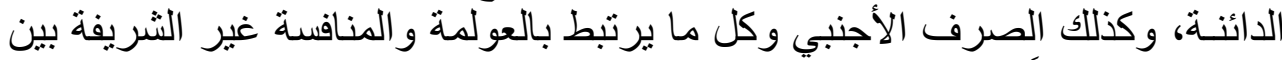

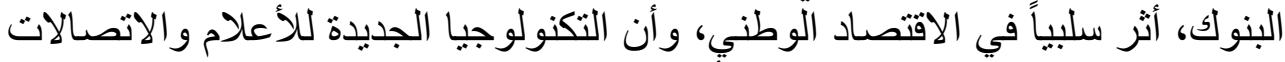

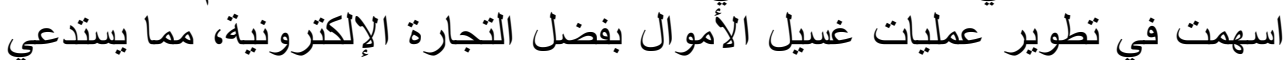




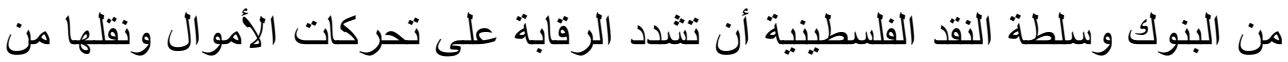

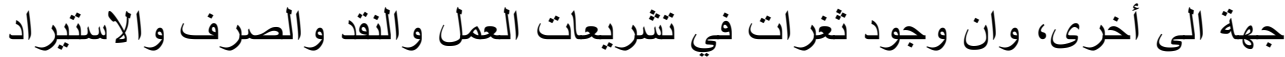

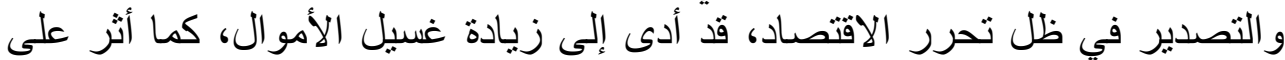

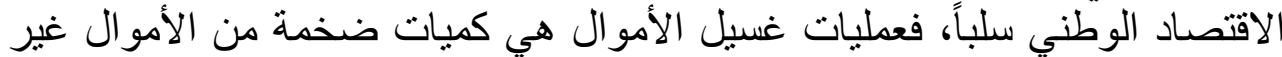

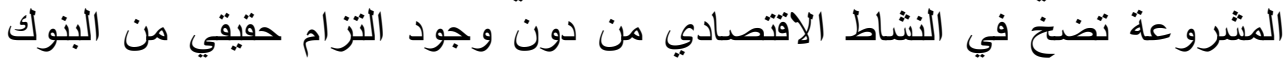

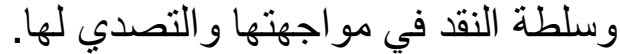

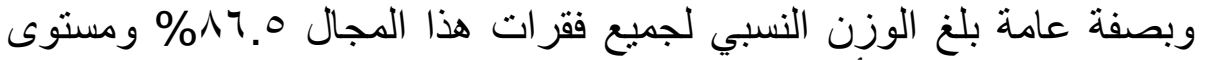

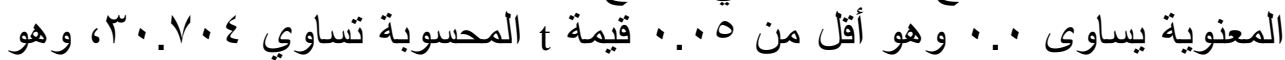

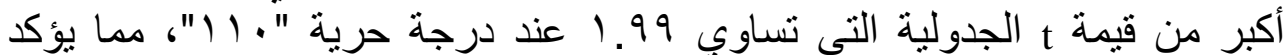

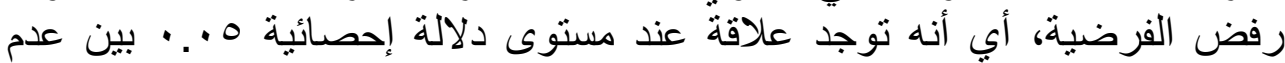

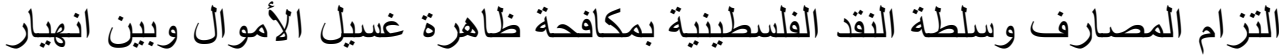
المؤسسات المالية الناجحة والتأثير السلبي على الاقتصاد الوطني.

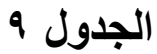

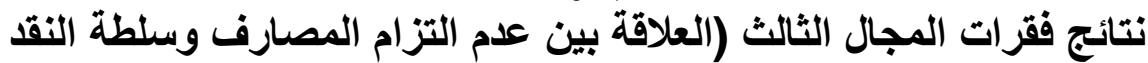

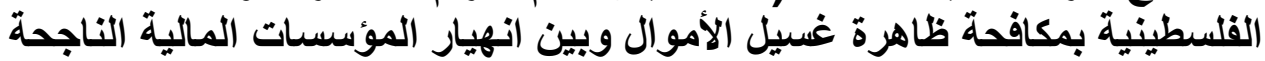

\begin{tabular}{|c|c|c|c|c|c|c|}
\hline 冏 & 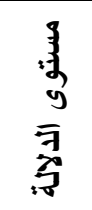 & 黑 & $\begin{array}{l}\overline{5} \\
: \overline{3} \\
\overline{9} \\
\end{array}$ & 产 & الفقرات & 3 \\
\hline 7 & $\therefore \cdots$ & r.o. & Nr. & «.1. & 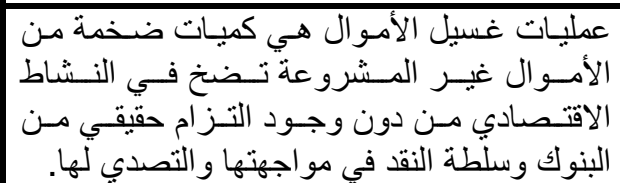 & 1 \\
\hline 0 & $\because \cdots$ & $r r_{.} r_{q}$ & $\wedge \varepsilon_{.}$. & $\varepsilon, r^{\prime}$ & 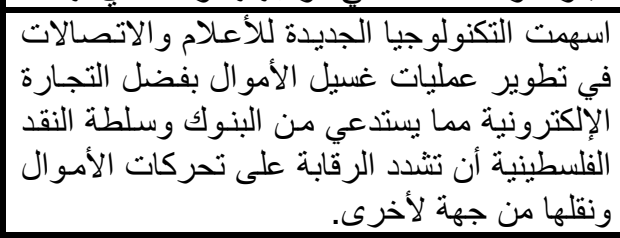 & r \\
\hline 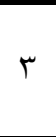 & $\therefore \cdots$ & $r .1 \leqslant T$ & Av. 9 & $\varepsilon . \varepsilon$ & 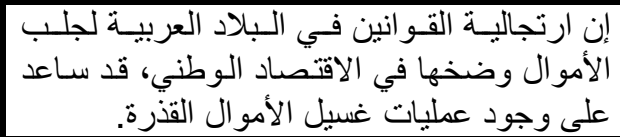 & $r$ \\
\hline & $\because \cdots$ & Tr.,$E_{0}$ & $\lambda \Lambda_{.}{ }^{\prime}$ & ६. ६1 & 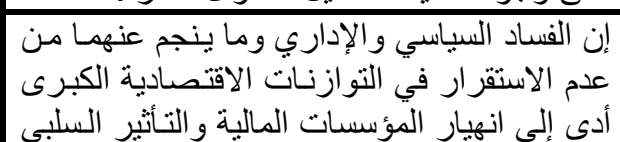 & $\varepsilon$ \\
\hline
\end{tabular}




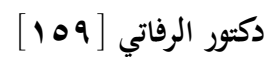

\begin{tabular}{|c|c|c|c|c|c|c|}
\hline 瑏 & $\begin{array}{l}3 \\
3 \\
y \\
\bar{y} \\
7\end{array}$ & :बु & $\begin{array}{l}\overline{3} \\
: 3 \\
\overline{7} \\
3\end{array}$ & $\overline{\bar{z}} \frac{\bar{y}}{\mathfrak{y}}$ & 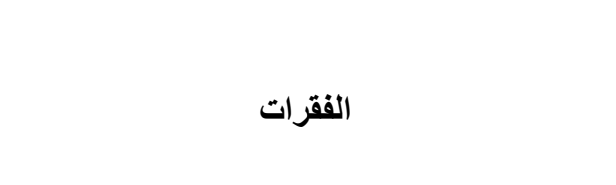 & 忽 \\
\hline & & & & & على الاقتصاد الوطني. & \\
\hline$\varepsilon$ & $\because \cdots$ & rI. r. & $\wedge \varepsilon .1$ & $\varepsilon . Y_{1}$ & 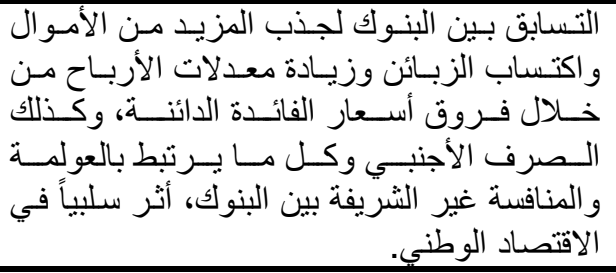 & 0 \\
\hline 0 & $\because \cdots$ & rI. .49 & $\Lambda \varepsilon$. & $\varepsilon . r \cdot$ & 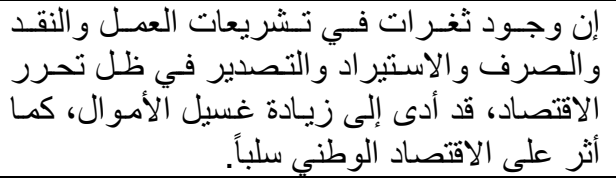 & 7 \\
\hline 1 & $\because \cdots$ & rT.OV. & $9 \cdot .1$ & $\varepsilon .0$ & 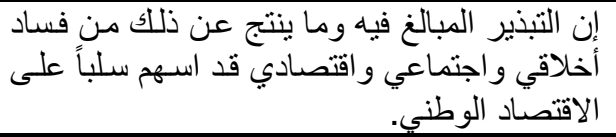 & V \\
\hline$r$ & $\because \cdots$ & $r r_{.} \mid \leq r$ & Av. 9 & $\varepsilon . \Sigma$ & 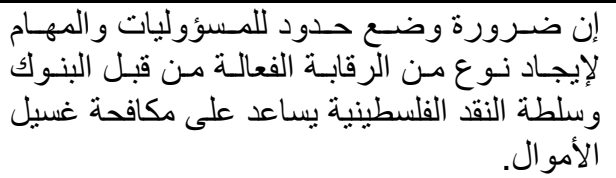 & $\wedge$ \\
\hline 1 & $\because \cdots$ & rT.OV. & $9 \cdot .1$ & $\varepsilon .0$ & 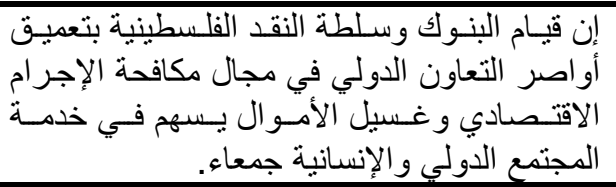 & 9 \\
\hline & $\because \cdots$ & $r \cdot . V \cdot \varepsilon$ & $\Lambda 7.0$ & $\varepsilon . M r$ & جميع فقرات المجال & \\
\hline
\end{tabular}

النتائج و التوصيات

النتائج

جريمة غسيل الأموال تؤثر سلباً في الحياة الاجتماعية والاقتصادية و السياسية في البلدان كافة ومن بدون استثناء.

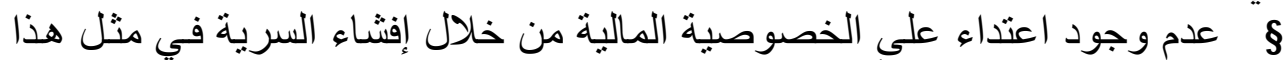

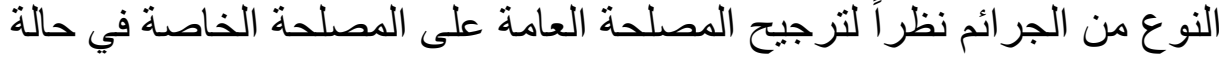
وجود خطر يهدد مصلحة المجنمع. ع عليات غسيل الأموال تؤدي إلى إنهيار القطاع المصرفي والمؤسسات المالية الناجحة.

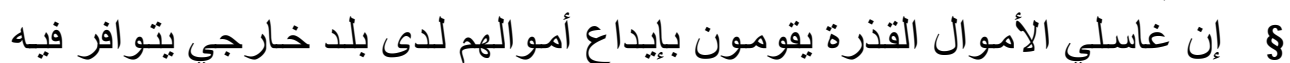

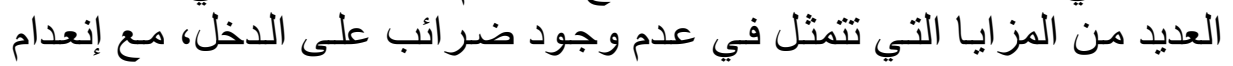


الرقابـة على البنوك وسـهولة تأسبس أو شر اء الشركات والاستقرار السياسي و النقبي، مع تو افر الاتصالات الحئة الحيثة. B

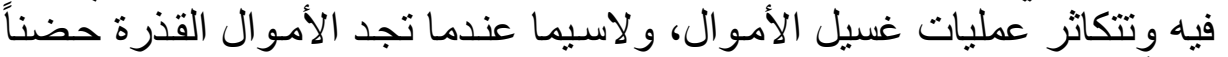

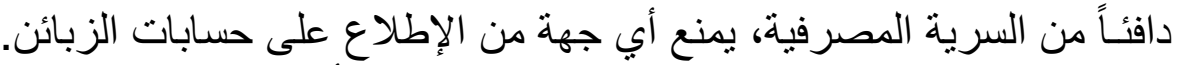

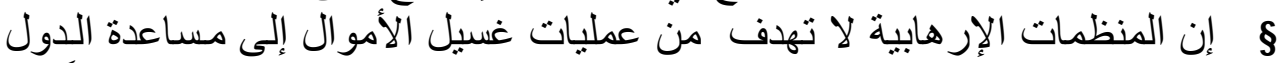

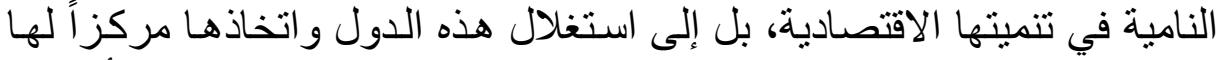

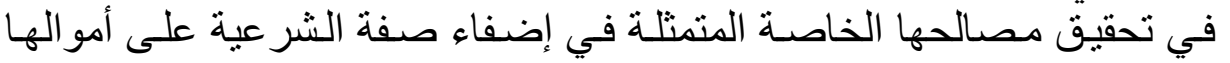
القذرة.

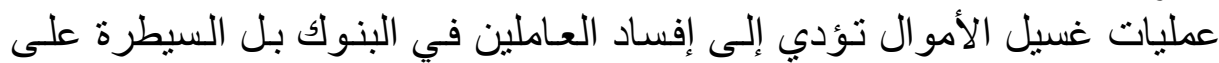

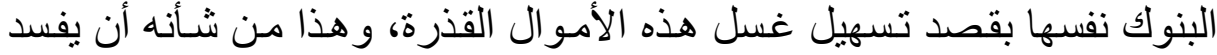

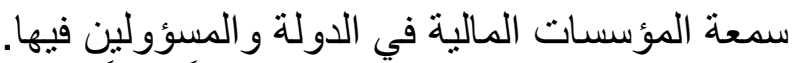

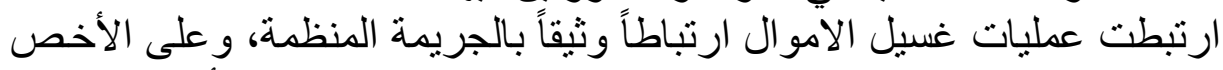

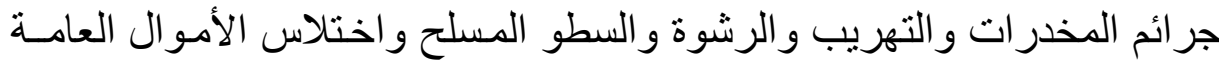

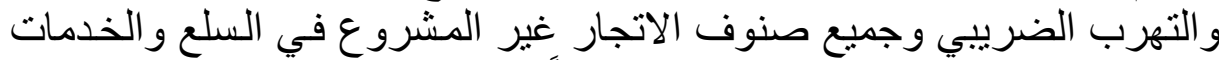

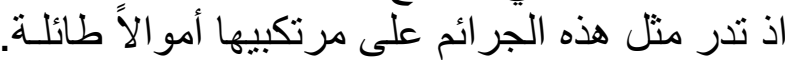

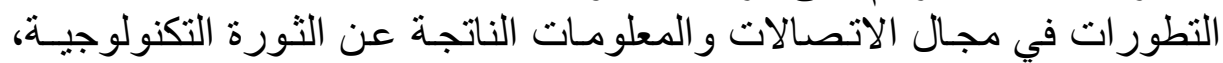

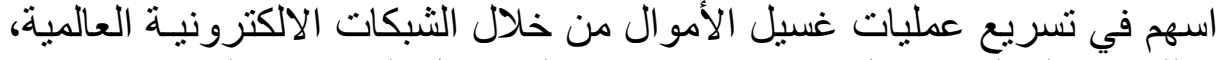

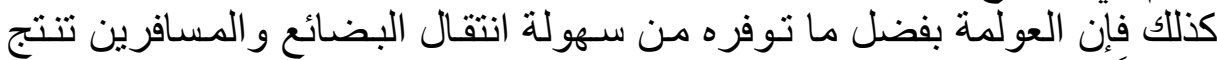

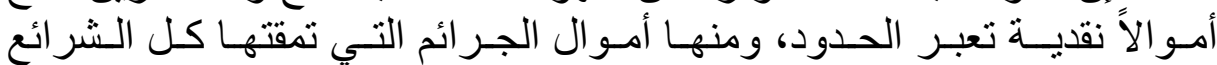

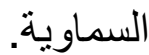

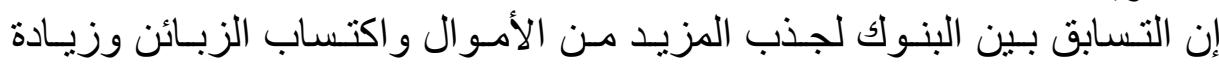

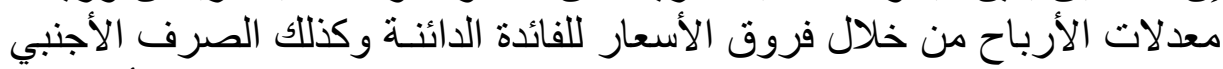

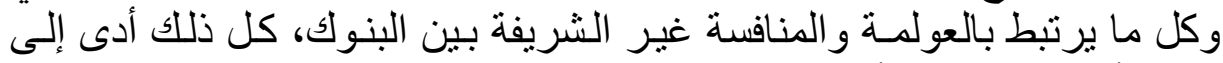

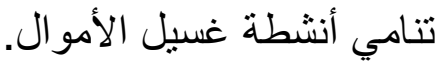

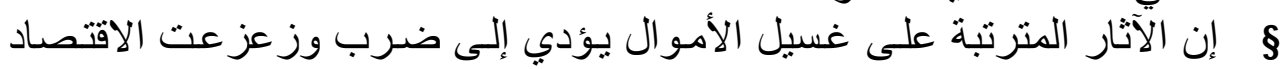

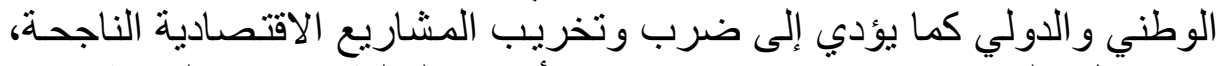

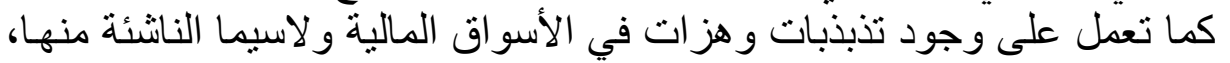
مما يؤدي إلى انهيار النظام المالي.

التوصيات

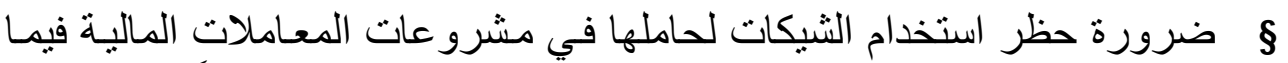

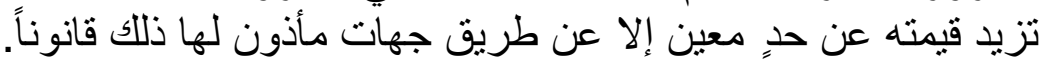

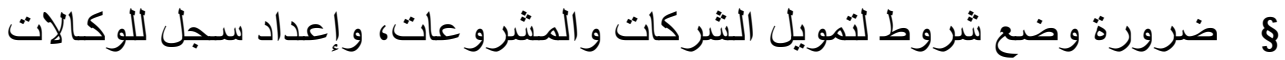

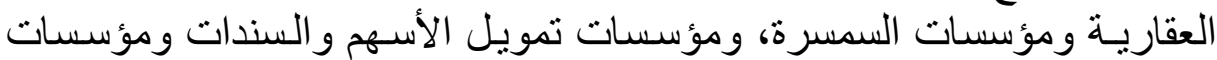
الاستثمار ، ومؤسسات التأمين و الوسطاء الذين يعملون في التمويل. 


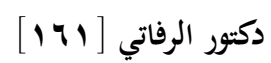

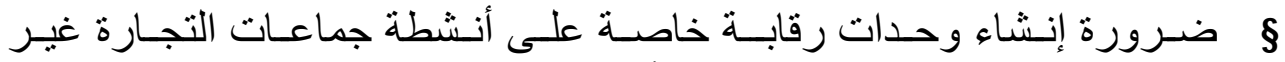
المشروعة و لاسيما المتعلقة بغسيل الأموال.

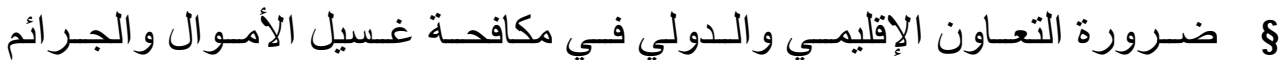

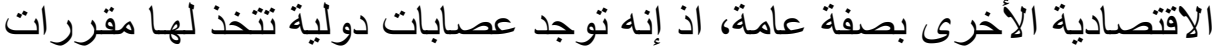

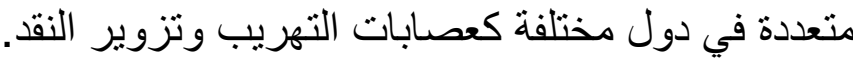

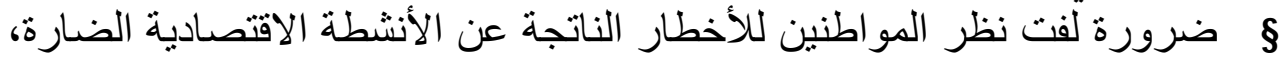

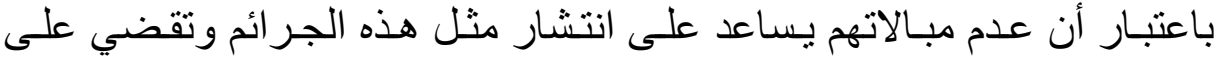

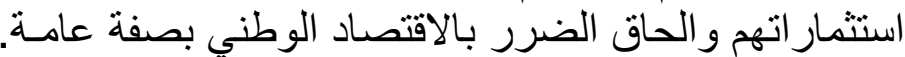

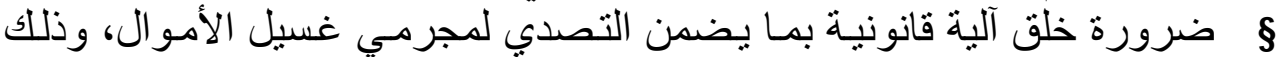

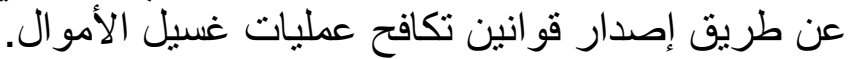

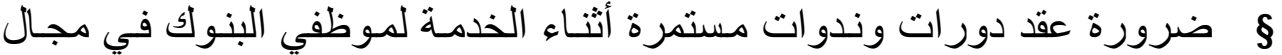

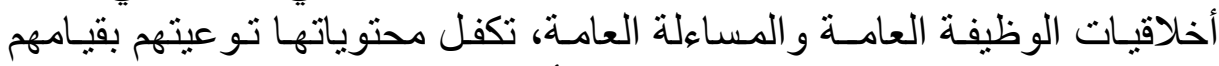
بو اجباتهم على نحو يكافح عمليات غسيل الأموات المال القذرة.

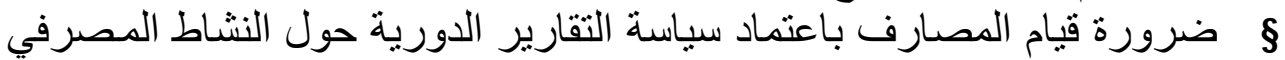

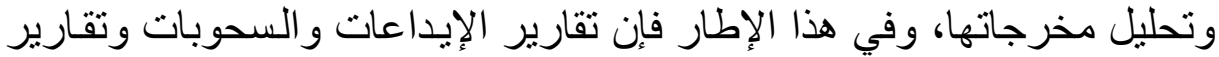

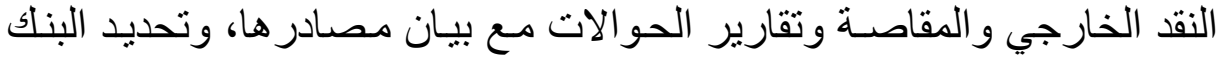

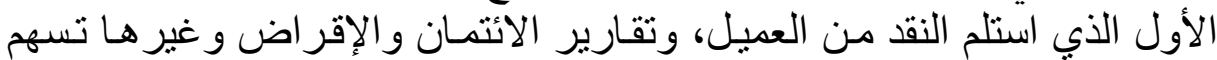

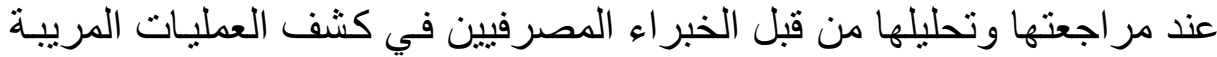

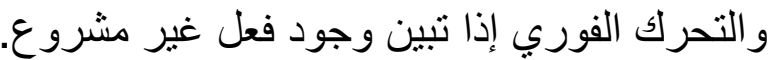

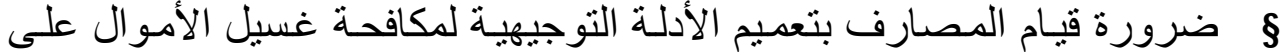

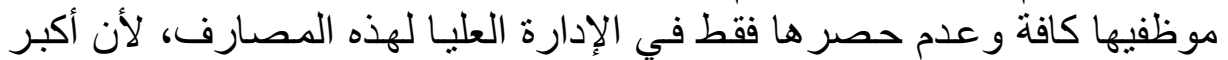

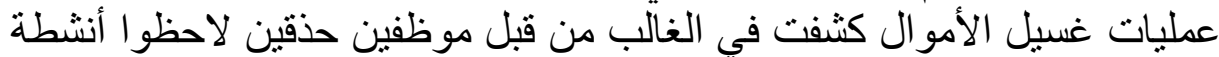

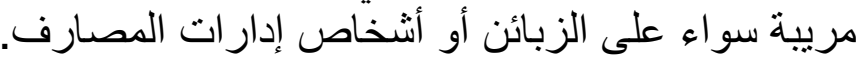

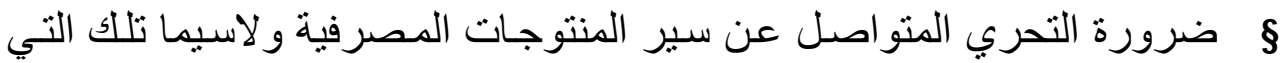

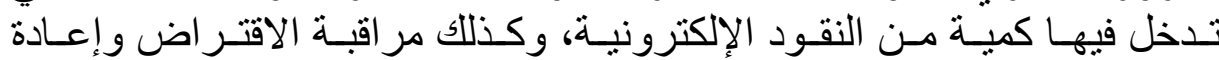

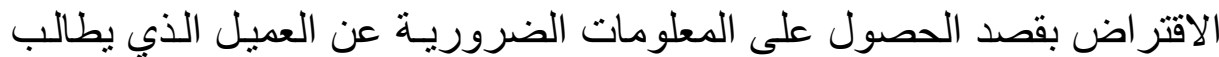

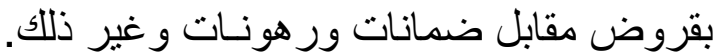

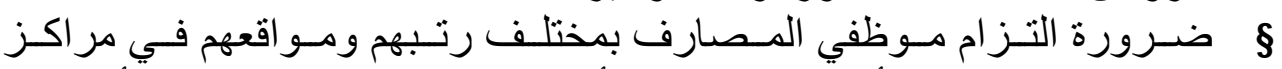
المسؤولية بالمبادئ الأساسية و المتعلقة بأساليب مكافحة ظاهرة غسيل الأمو ال.

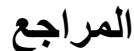

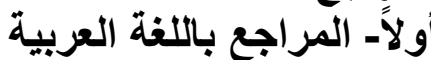

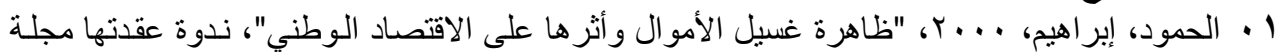

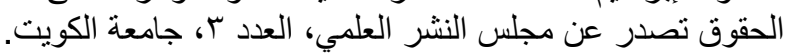

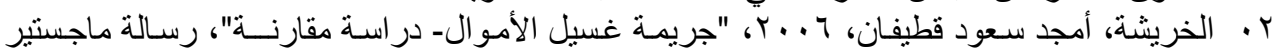

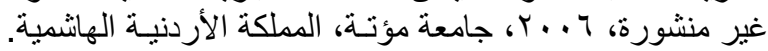




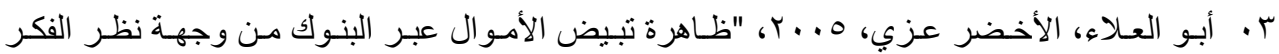

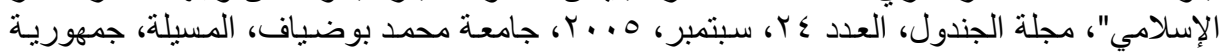

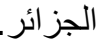

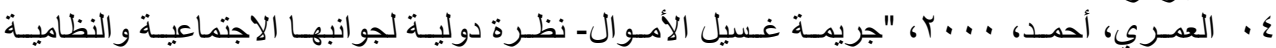

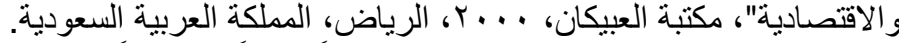

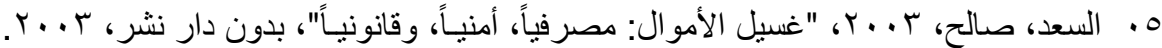

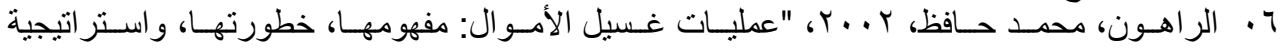

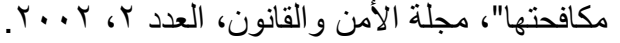

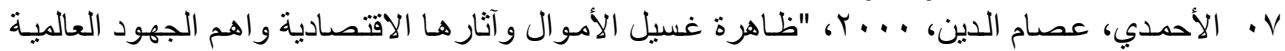

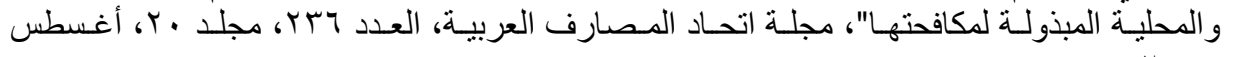
.r...

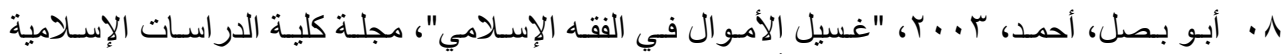

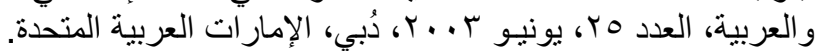

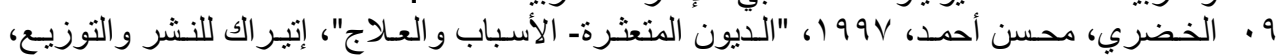

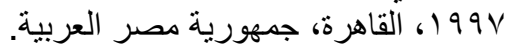

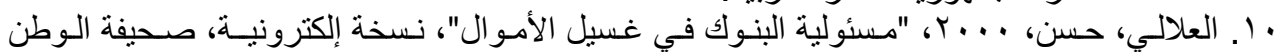

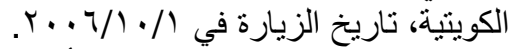

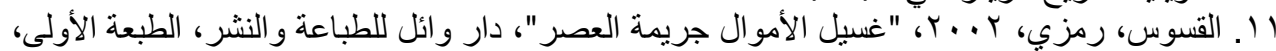

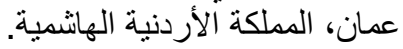

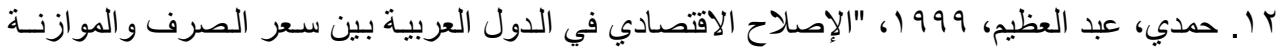

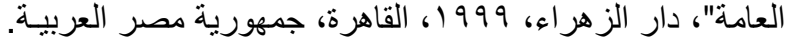

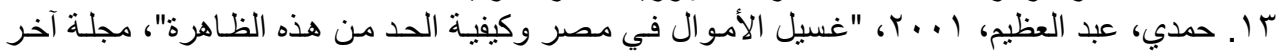

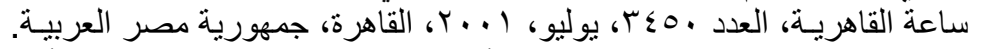

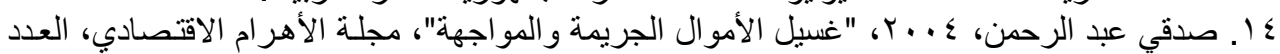

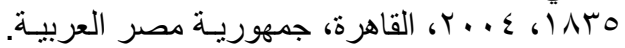

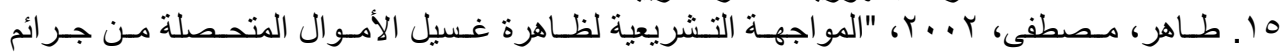

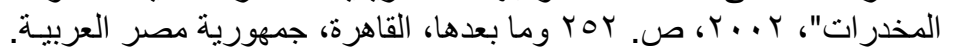

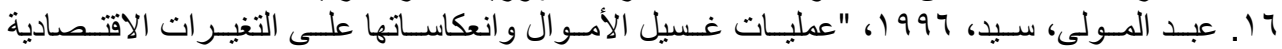

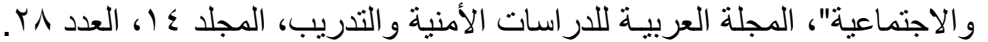

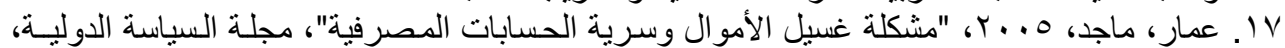

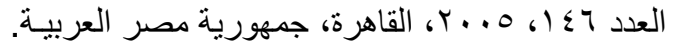

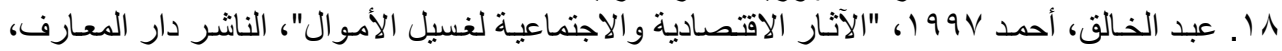

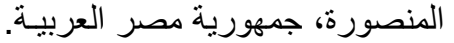

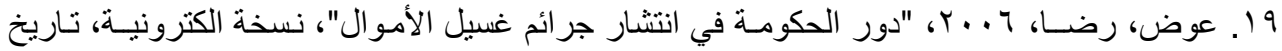

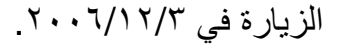

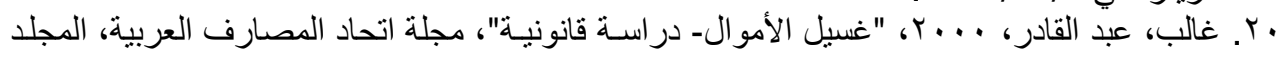

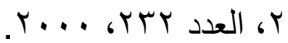

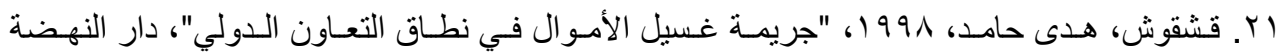

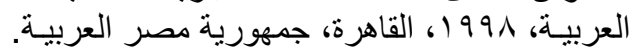

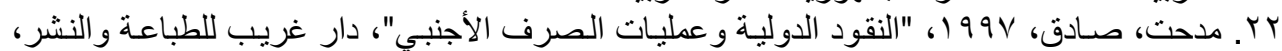

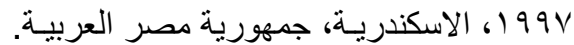

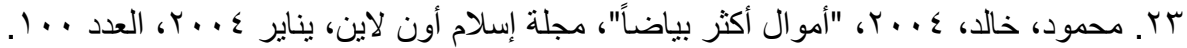

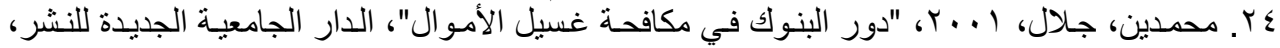

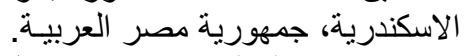

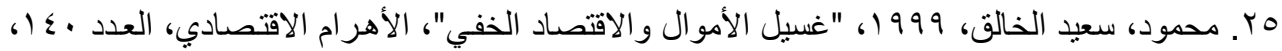
سبتمبر 1999 1، القاهرة، جمهورية مصر العربيـة. 


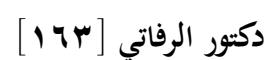

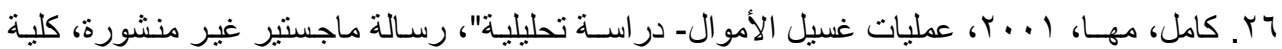

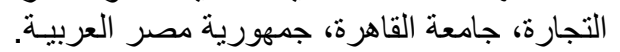

VV. T كويرك، بيتر . ج (بدون تاريخ)، "غسيل الأموال يثير الثكوك في الاقتصاد الكلي".

WWW.alwatan.Com/graphics/2000/oct.1.10/heads/ots.htm

WWW.egyptiangreens.com

\section{ثانياً. المراجع باللغة الإنجليزية}

1. Aullier, Joel (1994), "Macro Economie", Editions Economic, Paris, 1994, (www.local.attac.org/romane).

2. Henniessai, Ahmed (1992), "Sur Lecomomie Parallèle en Algérie", ENAG, 1992.

3. Jack Blum, A. (1999), "Financial Havens, Banking Secrecy and Money Laundering", United Nations Publications, New York, 1999.

4. Michael Levi (2000), "Money Laundering and Precedes of Crime", Journal of Money Laundering Control, Vol. 3, No (3), (Winter 2000). 